\title{
Vv-AMPI, a ripening induced peptide from Vitis vinifera shows strong antifungal activity
} Abré de Beer and Melané A Vivier*

Address: Institute for Wine Biotechnology, Department of Viticulture and Oenology, Faculty of AgriSciences, Stellenbosch University, Stellenbosch 7600, South Africa

Email: Abré de Beer - abre@sun.ac.za; Melané A Vivier* - mav@sun.ac.za

* Corresponding author

Published: 8 July 2008

BMC Plant Biology 2008, 8:75 doi:10.1 I86/I47/-2229-8-75
Received: 2 November 2007

Accepted: 8 July 2008

This article is available from: http://www.biomedcentral.com/147I-2229/8/75

(C) 2008 de Beer and Vivier; licensee BioMed Central Ltd.

This is an Open Access article distributed under the terms of the Creative Commons Attribution License (http://creativecommons.org/licenses/by/2.0), which permits unrestricted use, distribution, and reproduction in any medium, provided the original work is properly cited.

\begin{abstract}
Background: Latest research shows that small antimicrobial peptides play a role in the innate defense system of plants. These peptides typically contribute to preformed defense by developing protective barriers around germinating seeds or between different tissue layers within plant organs. The encoding genes could also be upregulated by abiotic and biotic stimuli during active defense processes. The peptides display a broad spectrum of antimicrobial activities. Their potent antipathogenic characteristics have ensured that they are promising targets in the medical and agricultural biotechnology sectors.

Results: A berry specific cDNA sequence designated Vv-AMPI, Vitis vinifera antimicrobial peptide 1 , was isolated from Vitis vinifera. $V v-A M P I$ encodes for a 77 amino acid peptide that shows sequence homology to the family of plant defensins. VV-AMPI is expressed in a tissue specific, developmentally regulated manner, being only expressed in berry tissue at the onset of berry ripening and onwards. Treatment of leaf and berry tissue with biotic or abiotic factors did not lead to increased expression of $V_{v}-A M P I$ under the conditions tested. The predicted signal peptide of $\mathrm{Vv}_{\mathrm{V}} \mathrm{AMPI}$, fused to the green fluorescent protein (GFP), showed that the signal peptide allowed accumulation of its product in the apoplast. Vv-AMPI peptide, produced in Escherichia coli, had a molecular mass of $5.495 \mathrm{kDa}$ as determined by mass spectrometry. Recombinant Vv-AMPI was extremely heatstable and showed strong antifungal activity against a broad spectrum of plant pathogenic fungi, with very high levels of activity against the wilting disease causing pathogens Fusarium oxysporum and Verticillium dahliae. The Vv-AMPI peptide did not induce morphological changes on the treated fungal hyphae, but instead strongly inhibited hyphal elongation. A propidium iodide uptake assay suggested that the inhibitory activity of $\mathrm{Vv}$-AMPI might be associated with altering the membrane permeability of the fungal membranes.
\end{abstract}

Conclusion: A berry specific cDNA clone, $V v-A M P I$, was isolated and characterized and shown to encode a plant defensin. Recombinant $\mathrm{Vv}$-AMPI displayed non-morphogenic antifungal activity against a broad spectrum of fungi, probably altering the membrane permeability of the fungal pathogens. The expression of this peptide is highly regulated in Vitis vinifera, hinting at an important defense role during berry-ripening. 


\section{Background}

Plants are constantly subjected to microbial attack, especially phytopathogenic fungi and use various defense strategies to protect themselves against disease. These defenses include the strengthening of the physical cell wall barriers [1] and the production of chemical and proteinaceous antimicrobial compounds [2-6]. Over the last 15 years it has become evident that small, basic, cysteinerich peptides also form part of the overall defense of plants against phytopathogens, contributing significantly to the innate immunity of plants [7-10]. It has been suggested that all plants possess such a peptide defense system [8]. The peptides range from 2-9 kDa in size and the best characterized examples are the thionins and defensins [7,8,10-15]. When first isolated, defensins were classified as $\gamma$-thionins, but were later renamed to plant defensins due to their structural and functional similarities to insect and human defensins [16-18].

Plant defensins are a family of basic, cysteine-rich peptides of between 45-54 amino acids in size. Structurally they consist of one $\alpha$-helix and one $\beta$-sheet, comprising three antiparallel $\beta$-strands, and stabilized by the formation of disulfide bridges between the cysteine residues [19-22]. Although plant defensins are structurally conserved, their overall homology at the amino acid level is low. However, most plant defensins contain eight cysteine residues linked by four disulfide bridges, an aromatic residue at position 11, two glycines at positions 13 and 34 and a glutamate at position 29 (numbering according to Rs-AFP1 [23]).

Most plant defensins exhibit some antimicrobial activity, inhibiting the growth of fungi, oomycetes and gram positive bacteria in vitro. The exact mechanisms underlying the antifungal activity exerted by plant defensins are not known, but there is evidence that plant defensins bind to a specific receptor in the fungal membrane, being sphingolipids, rather than random binding and integration into the phospholipid bilayer of the fungal membranes [2431]. Other biological activities such as proteinase and $\alpha$ amylase inhibition [22,32,33], metal tolerance [34], as well as the inhibition of protein translation and HIV proliferation have also been reported for some of the isolated plant defensins [35-37].

The majority of defensins have been isolated from plant seeds [35-43], but defensins have also been isolated from leaves [23,44], flowers [45-49], tubers [50], seedpods [38], as well as from fruits [51-53]. Although plant defensins play an important role in the preformed defense, some members of the defensin family are also upregulated upon pathogen attack or by environmental stimuli, while the expression of others are strictly developmentally regulated [34,51,52,54-59].
Here we report the isolation and characterization of the first plant defensin from Vitis vinifera. The peptide encoding gene shows a strict tissue-specific and developmentally regulated expression pattern. The peptide is strongly antifungal without inducing morphological changes to the hyphae of the tested fungi, but with an indication of a compromising effect on the fungal membrane. The ripening-specific expression pattern in berries and the strong in vitro antifungal characteristics of the isolated peptide draws interest to its possible in vivo role in berry defence systems.

\section{Results}

\section{Isolation and genomic characterization of Vv-AMP I}

Initial screening of the Vitis vinifera EST database at The Institute for Genomic Research (TIGR) with the BLAST algorithm yielded only one EST hit, TC69032. Subsequent analyses of the available databases after the completion of the grapevine genome sequence, has yielded other putative defensin sequences (results not shown). Primer design was based on the EST TC69032 and PCR screening of cDNA batches made from grapevine root, leaf and berry material allowed for the isolation of a single complete coding sequence from grape berry cDNA. The sequence was termed Vitis vinifera antimicrobial peptide $1(V v$ $A M P 1)$, because of its homology to the family of plant defensins. The complete coding sequence of $V v$-AMP1 is $234 \mathrm{bp}$ in size and encodes for a predicted 77 amino acid peptide, comprising a 30 amino acid signal peptide and a 47 amino acid mature peptide (Figure 1A). The genomic copy isolated for $V v$-AMP1 is 742 bp in size and comparative analyses with the cDNA sequences revealed that a 508 bp intron interrupts the predicted signal peptide (Figure $1 \mathrm{~B})$.

Southern blot analysis conducted on genomic DNA from cultivar Pinotage revealed the presence of two hybridization signals for $V v$-AMP1 within the $V$. vinifera genome (Figure 2). BLAST analysis of the grapevine genome sequence at the National Centre for Biotechnological Information (NCBI) identified two possible contig sequences, VV78X055073.5 and VV78X034124.3. Alignment analysis of these two genomic sequences showed that the nucleotide areas upstream and downstream of the $V v$-AMP1 open reading were similar, suggesting that a single copy of $V v$-AMP1 is present in the $V$. vinifera genome.

Alignment analysis of the genomic sequences of $V v$-AMP1 isolated from non-vinifera Vitis species revealed a high level of homology (93\%) at nucleotide level. When the deduced coding sequences for the different $V v$-AMP1 genes were compared, up to $95 \%$ homology was observed, translating into 93\% identity at the deduced amino acid level (Figure 3). $V v$-AMP1 from $V$. vinifera showed the highest homology to the gene amplified from 


\section{A}

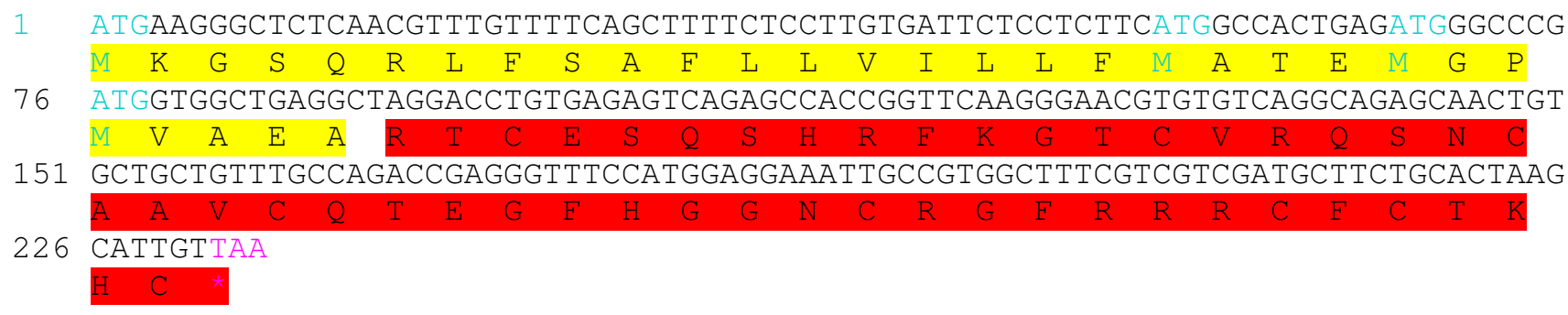

B

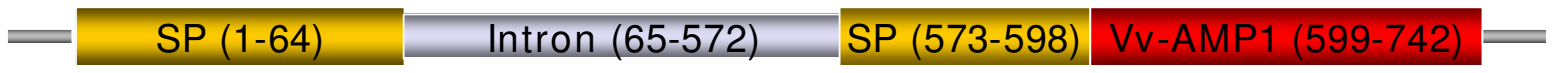

Figure I

Gene structure of $V v$-AMPI. (A) The complete coding sequence of $V v-A M P I$ with its deduced amino acid sequence. The amino acids in yellow represent the signal peptide while red amino acids indicate the mature peptide. (B) The genomic structure of the $V_{v-A M P I}$ gene. Yellow blocks represent the sequence encoding for the signal peptide of $\mathrm{Vv}-\mathrm{AMPI}$ and the red block the sequence encoding for the mature $\mathrm{Vv}$-AMPI peptide. The intron is indicated as a grey block. Numbering inside each block corresponds to the number of base pairs in each section.

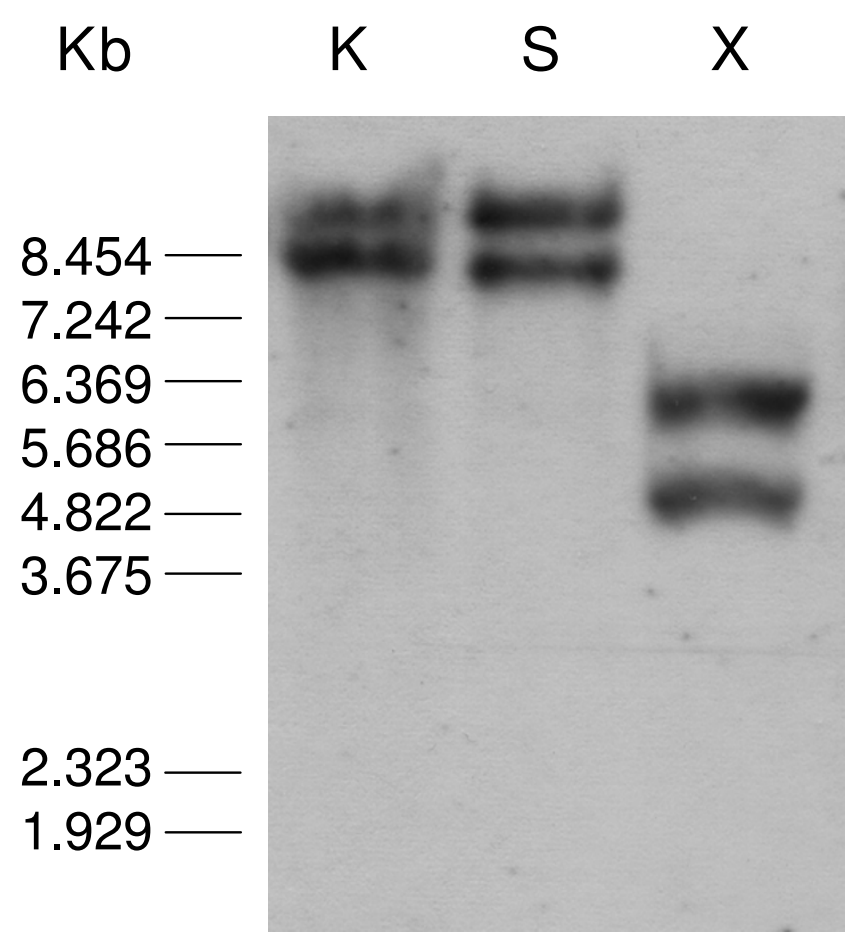

Figure 2

Southern blot analysis of Vitis vinifera genomic DNA to evaluate the genomic organisation of $V v-A M P I$. Vitis vinifera cv. Pinotage genomic DNA was digested with Kpnl (K), Spel (S) or Xbal (X) and probed with a DIG labeled cDNA copy of $V v-A M P I$. Lambda DNA digested with BstEll was used as marker (sizes indicated). Each signal indicates a single copy of $V v-A M P I$.
V. afganista, sharing $98.7 \%$ homology at amino acid level. The deduced amino acid sequences from $V$. vinifera and $V$. afganista differed from the rest by having one additional amino acid in their signal peptide region, with the introduction of isoleucine at position 15 (numbering according to Vv-AMP1 from $V$. vinifera).

\section{Bioinformatical characterization of the deduced amino acid sequence of $\mathbf{V}$-AMPI}

BLASTP results and further alignment analysis showed that the deduced amino acid sequence of $V v$-AMP1 shared high homology to the $\gamma$-thionins from Castanea sativa and PPT from petunia (Figure 4). Vv-AMP1 also displays the following conserved amino acid residues: an aromatic residue at position 11, two glycine residues at positions 13 and 34 and a glutamate at position 29, as well as the eight cysteine residues at positions $4,15,21,25,36,46,48,52$ present in all plant defensins (numbering according to RsAFP1 [23]). Disulfide bridge analysis done with DIpro showed that the eight cysteine residues of $\mathrm{VV}$-AMP1 are connected by four disulfide bridges (Figure 4).

Comparative homology modeling of the deduced amino acid sequence confirmed that the tertiary structure of $\mathrm{VV}$ AMP1 closely resembled that of hordothionin- $\gamma$ (1GPT) from barley and had the typical defensin structure consisting of an $\alpha$-helix and a triple-stranded antiparallel $\beta$-sheet, which are organized in a $\beta \alpha \beta \beta$ configuration (Figure 5). The structure is stabilized by intramolecular disulfide linkages between the eight cysteine residues. 


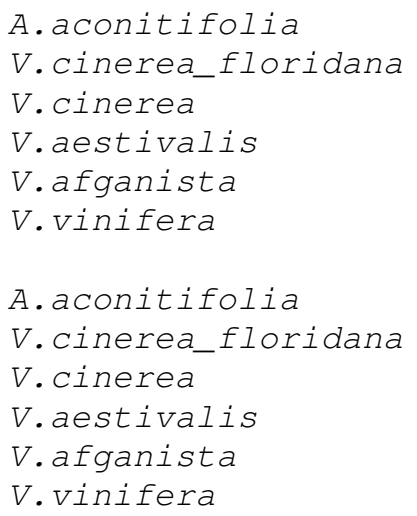

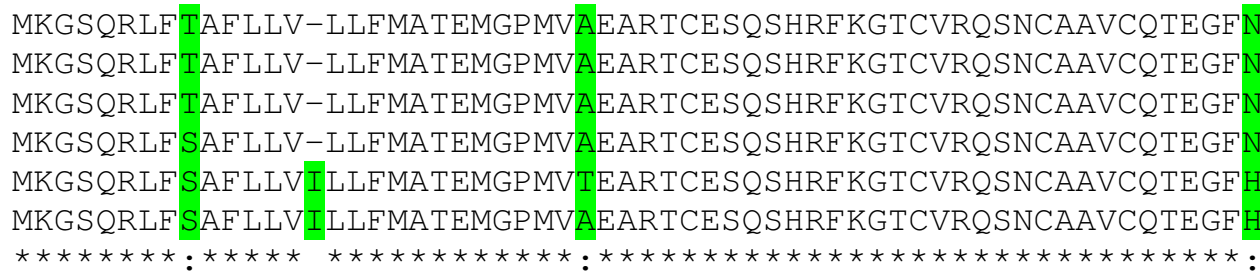

\section{Figure 3}

Alignment analysis of the deduced amino acid sequences of the Vv-AMPI genes isolated from different Vitis species. The major differences are indicated in green, note the additional amino acid at position 15 of the sequences isolated from $V$. vinifera and $V$. afganista (numbering according to $V_{v}$-AMPI from $V$. vinifera).

\section{Targeting ability of the putative Vv-AMPI signal peptide} PA-SUB predicted that the signal peptide of Vv-AMP1 directs its product to the apoplastic regions of plant cells. This was confirmed by fusing the Vv-AMP1 signal peptide to GFP under constitutive expression and overexpressing it into tobacco. Inverted fluorescent microscopy conducted on free-hand cross sections of the tobacco leaf petiole revealed that the GFP accumulated in the apoplastic regions (Figure 6).

\section{Expression profile of Vv-AMP I within V. vinifera}

Our investigation of the expression pattern of $V v$-AMP1 within grapevine, revealed that this gene is expressed in a tissue-specific manner, being only expressed in berries (Figure 7A). Northern blot analysis on berries in different stages of development and ripening confirmed that the gene is developmentally regulated. $V v$-AMP1 expression was induced upon berry ripening, starting at véraison, 11 weeks post-flowering (Figure $7 \mathrm{~B}$ ). Expression of $V v$-AMP1 remained high throughout the rest of the berry ripening stages. Induction studies, conducted on grapevine leaf material, simulating osmotic stress, wounding, pathogen infection with Botrytis cinerea as well as treatment with ABA, were unable to induce $V v$-AMP1 expression (Figure $7 \mathrm{C})$. The experiment was also repeated on pre-véraison berries, but none of the induction stimuli could overcome the developmental regulation (results not shown). On the pre-véraison berries, JA and SA treatments were included without any induction observed (results not shown).

\section{Recombinant production of Vv-AMPI}

Recombinant Vv-AMP1, fused to the GST-tag, was successfully produced in E. coli by using the Rosetta gami pLysS expression system. Purification of the recombinant pep- tide using a glutathione affinity chromatography system (Sigma, St Louis, USA) yielded $5 \mathrm{mg} / \mathrm{L}$ purified peptide. The recombinant fusion protein had a size of $31 \mathrm{kDa}$, consistent with the predicted size. Successful removal of the GST-tag was achieved by thrombin cleavage and confirmed with SDS-PAGE analyses and western blot analysis (Figure 8A). Recombinant peptide was successfully separated from the cleaved tag, using ion exchange chromatography, and desalted on a C8 column. Mass spectrometry revealed that the recombinant peptide had a size of 5.495 $\mathrm{kDa}$, which matched the predicted mass (Figure 8B). Peptide mass fingerprinting confirmed that recombinant $\mathrm{Vv}$ AMP1 resulted from the DNA sequence encoding for the mature Vv-AMP1 peptide.

\section{Antimicrobial activity of Vv-AMPI}

Recombinant Vv-AMP1 was tested against several plant pathogenic fungi using a dose-response growth inhibition assay. The activity of Vv-AMP1 on fungal hyphae was assessed by incubating fungal spores in the presence of various concentration of VV-AMP1 over a 72 hour period, with the $\mathrm{IC}_{50}$ value being determined after 48 hours of incubation (Figure 9A-D). Vv-AMP1 had a severe effect on the accumulation of fungal biomass over time in all of the fungal isolates tested and was most active against $F$. oxysporum (Figure 9B) and V. dahliae (Figure 9D), the two causal agents of wilting disease, with $\mathrm{IC}_{50}$ values of $6 \mu \mathrm{g} /$ $\mathrm{ml}$ and $1.8 \mu \mathrm{g} / \mathrm{ml}$, respectively. $\mathrm{Vv}$-AMP1 was however less effective against $F$. solani with an $\mathrm{IC}_{50}$ value of $9.6 \mu \mathrm{g} /$ $\mathrm{ml}$ (Figure 9A). The necrotrophic fungi B. cinerea (Figure 9C) was inhibited with an $\mathrm{IC}_{50}$ value of $13 \mu \mathrm{g} / \mathrm{ml}$. Treatment of $B$. cinerea spores with peptide concentrations above $15 \mu \mathrm{g} / \mathrm{ml}$ resulted in > 95\% growth inhibition, while a concentration of $30 \mu \mathrm{g} / \mathrm{ml}$ completely arrested 


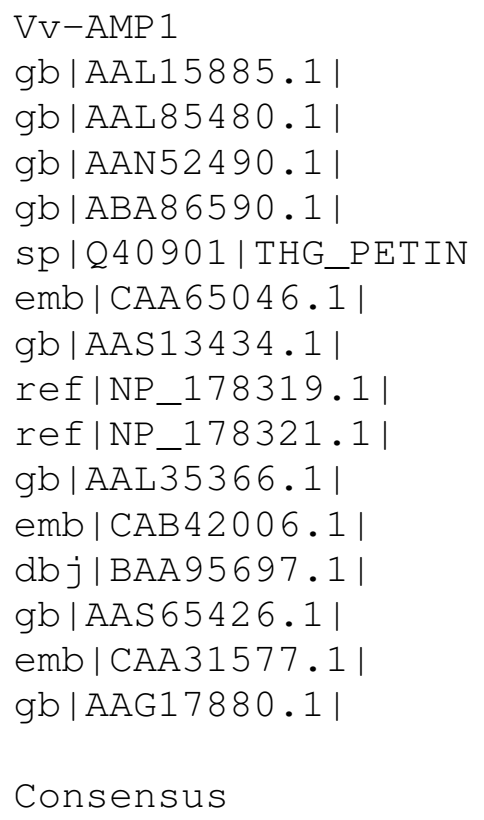

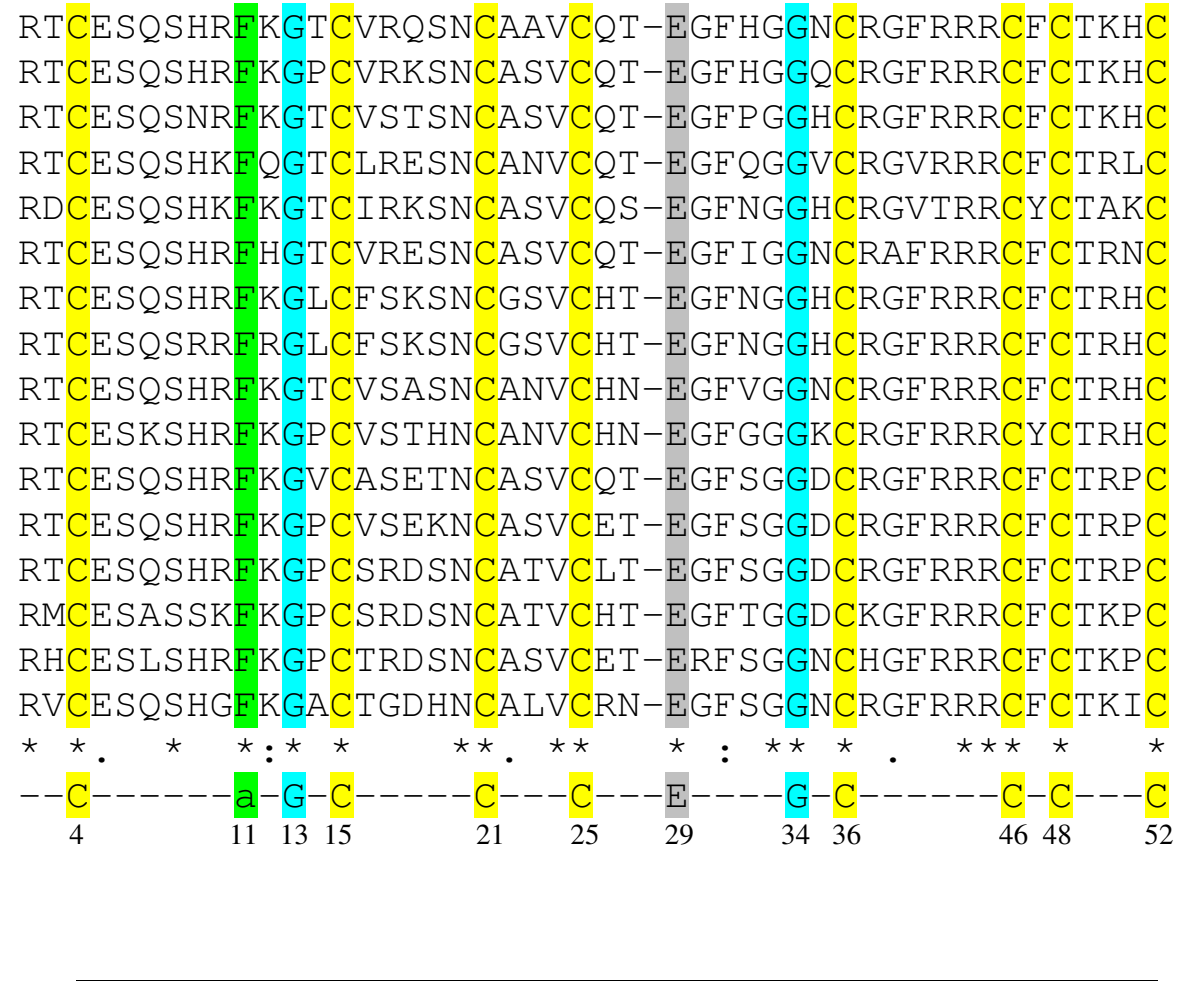

\section{Figure 4}

Amino acid alignment analyses of plant defensins belonging to subfamily $B$ I and Vv-AMPI from Vitis vinifera. gb|AALI 5885.I| putative $\gamma$-thionin [Castanea sativa]; gb|AAL85480.I| defensin protein I [Prunus persica]; gb|AAN52490.I] defensin EGADI [Elaeis guineensis]; gb|ABA86590.I] putative defensin I [Aquilegia olympica]; sp|Q4090I|THG_PETIN $\gamma$-thionin homolog PPT precursor [Petunia inflata]; emb|CAA65046.I unnamed protein product [Capsicum annuum]; gb|AASI3434.I] defensin [Nicotiana attenuata]; ref|NP_I783 19.I| LCR69/PDF2.2; protease inhibitor [Arabidopsis thaliana]; ref|NP_I7832I.I| LCR68/PDF2.3; protease inhibitor [Arabidopsis thaliana]; gb|AAL35366.I| defensin protein precursor [Capsicum annuum]; emb|CAB42006.I $\gamma$-thionin [Lycopersicon esculentum]; dbj|BAA95697.I| thionin like protein [Nicotiana tabacum];

gb|AAS65426.I| Kunitz-type trypsin inhibitor ['pomoea batatas]; emb|CAA31577.I unnamed protein product [Solanum tuberosum]; gb|AAG 17880.I| Kunitz trypsin inhibitor protein [Phaseolus coccineus]. The consensus sequence common to all defensins is indicated below with numbering according to Rs-AFPI [23]. The eight cysteines are indicated in yellow and the aromatic residue at position II in green. The conserved glycines are indicated in blue and glutamate at position 29 in grey. The gap was introduced to have number agreement with Rs-AFPI. The disulfide bridge organization within the Vv-AMPI sequence is indicated below the consensus sequence.

spore germination (data not shown). The peptide showed no inhibition of $A$. longipes, even at peptide concentrations above $20 \mu \mathrm{g} / \mathrm{ml}$ (results not shown).

Microscopical analyses of fungal hyphae treated with VvAMP1 showed no signs of the characteristic hyperbranching effect associated with some plant defensins. Vv-AMP1 did, however, severely alter the ability of fungal hyphae to elongate and most hyphal tips had a swollen appearance. Granulation of the hyphal cytoplasm was also observed in most fungi treated with Vv-AMP1 (data not shown).

A propidium iodine treatment combined with fluorescent microscopy showed high levels of fluorescence present in the Vv-AMP1 treated samples when compared to the untreated fungi that showed no fluorescence (Figure 10). This is an indication that the fungal membranes were compromised by the presence of the Vv-AMP1 peptide. Fluorescence was observed throughout the affected hyphae in both Fusarium strains (Figure 10), whereas fluorescence was only present at the tips of VV-AMP1 treated hyphae from $V$. dahliae (Figure 10L).

\section{Recombinant Vv-AMPI is heat-stable and sensitive to proteinase activity in preliminary stability assessments} Vv-AMP1 was tested for its stability at different temperatures using an antifungal growth assay against Botrytis cinerea (Figure 11A). Vv-AMP1 showed remarkable stability 
A

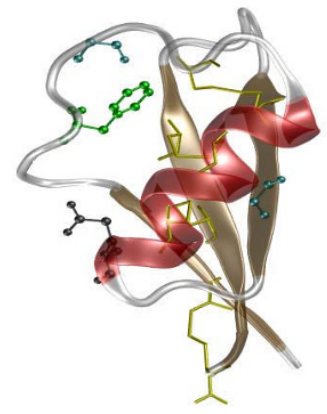

B

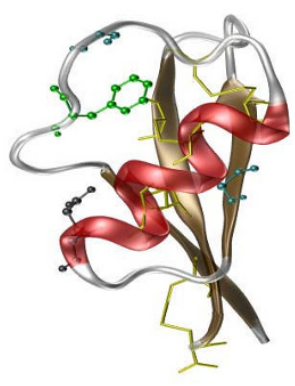

Figure 5

Comparison of the tertiary structure of $\mathrm{Vv}$-AMP I from grapevine (A) and hordothionin- $\gamma$ from barley (B). The $\alpha$-helix and $\beta$-sheet structures are represented in red and ochre respectively with the conserved amino acids represented in ball and stick models and colored according to the conserved sequence in Figure 4.

at temperatures up to $100^{\circ} \mathrm{C}$. Ninety five percent of its antifungal activity was retained after $30 \mathrm{~min}$ of treatment at $80^{\circ} \mathrm{C}$ and $62 \%$ at $100^{\circ} \mathrm{C}$ for $30 \mathrm{~min}$.

Vv-AMP1 was very sensitive to proteinase $\mathrm{K}$ treatment, confirming its proteinaceous nature. Enzyme treatment at $100 \mu \mathrm{g} / \mathrm{ml}$ totally abolished the activity of $\mathrm{Vv}$-AMP1, as determined by an antifungal assay against $V$. dahliae (Figure $11 \mathrm{~B})$.

\section{Discussion \\ The isolation and characterisation of a plant defensin encoding gene from grapevine}

Plant defensins are small, cysteine-rich peptides with a basic nature that exhibit a broad spectrum of antimicrobial activity and have been implicated in the innate defense system of plants. Here we report the isolation and characterization of the first defensin peptide and its encoding gene from Vitis vinifera, the world's most important fruit crop. The 234 bp open reading frame isolated from $V$. vinifera berry cDNA (Figure 1 ) encoded VV-AMP1, a peptide with significant consensus and structural homology to the peptide family of plant defensins. Analysis of the grapevine genome revealed that only one copy of $V v$-AMP1 is present in the Vitis vinifera genome and the two hybridization signals observed in the Southern blot analysis are due to heterogeneity in the $V v$-AMP1 locus. Moreover, the isolated gene is highly conserved within the Vitis genus (Figure 3). Most of the non-vinifera Vitis spp. that yielded homologous sequences are known for their high levels of natural resistance against fungal pathogens. Bioinformatical analyses on these sequences in comparison with the $V$. vinifera sequence showed high levels of homology and shared deduced structural features. The recently completed grapevine genome sequence revealed additional putative defensin sequences in Vitis vinifera (results not shown) that could be targeted for isolation and characterization as well.

Plant defensins exhibit an array of expression profiles and can be expressed constitutively, in a tissue specific pattern and also induced by various environmental stimuli [34,52,54-60]. The expression profiling of $V v$-AMP1 showed that this gene is highly regulated. $V v$-AMP1 showed a tissue-specific and developmentally regulated expression pattern, being only expressed in grape berry material (Figure 7A-B). Under the conditions tested, no additional inducers were observed and none overcame the berry-specific and developmentally regulated expression pattern (Figure 7C). The lack of response to wounding and infection by the known grapevine pathogen, $B$. cinerea, suggests that regulation of $V v$-AMP1 expression is independent of the plant defense signalling pathways directed by these external stimuli. Hormone treatments in berries included SA, JA and ABA, but none of these showed any induction under the conditions tested. The expression pattern of $V v$-AMP1 corresponds to berry ripening and it will be important to evaluate the effect of brassinosteroids further since it has recently been shown that these compounds act as inducers of berry ripening [61]. ABA is similarly linked to berry ripening, but did not have any effect on $V v$-AMP1 expression levels. The specific expression pattern of this defensin gene is interesting and opposite to many genes linked to defence in grape berries. Transcriptome analysis and other studies have shown that many defence-related genes are down-regulated at the onset of berry ripening. It has been hypothesized that the defence mechanisms of the berry is not maintained during the post-véraison stages since the seed, containing the matured embryo, has obtained its hardened and protective seed coat when the berry starts to ripen. The plant has therefore completed its reproductive cycle and defence in berries are (from the perspective of the plant) less important. The signal peptide of Vv-AMP1 was shown to target GFP to the apoplastic regions when overexpressed in transgenic tobacco (Figure 6). Tissue-localization in the grape berries will provide further clues to the possible in planta role(s) of this peptide, specifically in relation to berry defence.

\section{Vv-AMPI: a highly stable and potent inhibitor of a range of fungal pathogens}

Characteristic features of $\mathrm{Vv}-\mathrm{AMP}$ I

Comparative analysis of the mature $\mathrm{Vv}$-AMP1 with other members of the defensin family revealed that $\mathrm{Vv}$-AMP1 shared the conserved amino acids present in the majority of plant defensins and was closest related to the defensin PPT from petunia (Figure 4). Classification studies, based on the precursor protein structure, grouped Vv-AMP1 with 

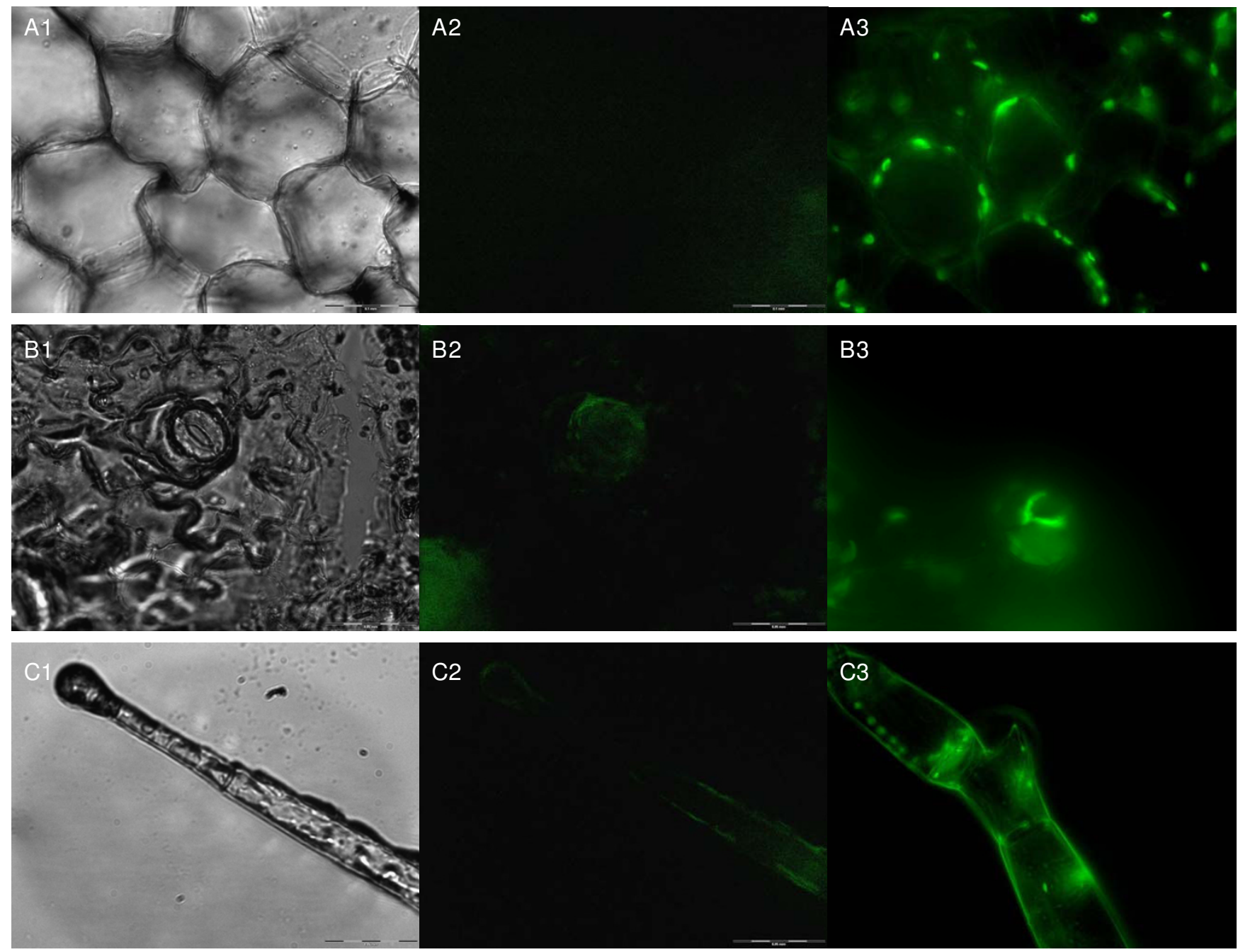

Figure 6

Localization of GFP in transgenic tobacco as directed by the signal peptide of Vv-AMPI. Localization of GFP observed in the apoplasts of the following tissues, organs and cells in the leaf petiole: $(\mathbf{A})$ cortex; (B) the guard cells of the stomata and $(\mathbf{C})$ the trichoma. $\mathrm{AI}, \mathrm{BI}$ and $\mathrm{Cl}$ show light microscopic photos of these various tissues and organs from the untransformed control. A2, B2 and C2 show the auto-fluorescence from these same fields in the untransformed controls, whereas A3, B3 and C3 indicate GFP expression in the apoplastic regions of these structures in the GFP overexpressing lines.

Class I of the defensin family [8]. Class I defensin peptides have a conserved precursor protein structure that consists of a N-terminal signal peptide followed by a mature defensin domain [8].

The Vv-AMP1 gene was successfully overexpressed in E. coli to yield purified peptide which could be subjected to accurate determination of size, as well as peptide fingerprinting. These results, as well as western blot analysis confirmed that the peptide was purified to homogeneity. The purified peptide was shown to be highly heat-stable, but readily deactivated by protease treatment. Preliminary results (not shown) indicates that $\mathrm{Vv}$-AMP1 is quite sensitive to the divalent cation $\mathrm{Ca}^{2+}$ when evaluated against $B$. cinerea. The sensitivity to cations is a characteristic well documented for many members of the plant defensin family [14,15], but is highly dependent on the fungal pathogen tested. Since the peptide is targeted to the apoplastic area, this indication of $\mathrm{Ca}^{2+}$ sensitivity, as well as other cations, will have to be tested further against a broader range of fungi, specifically against the fungal pathogens of grapevine.

\section{Inhibition profile and antifungal characteristics of $\mathrm{Vv}-\mathrm{AMPI}$}

The panel of pathogens tested included various wilting disease pathogens as well as Botrytis, as a grapevine pathogen. Many of the grapevine fungal pathogens cannot be cultured in vitro (such as the powdery and downy mildew 


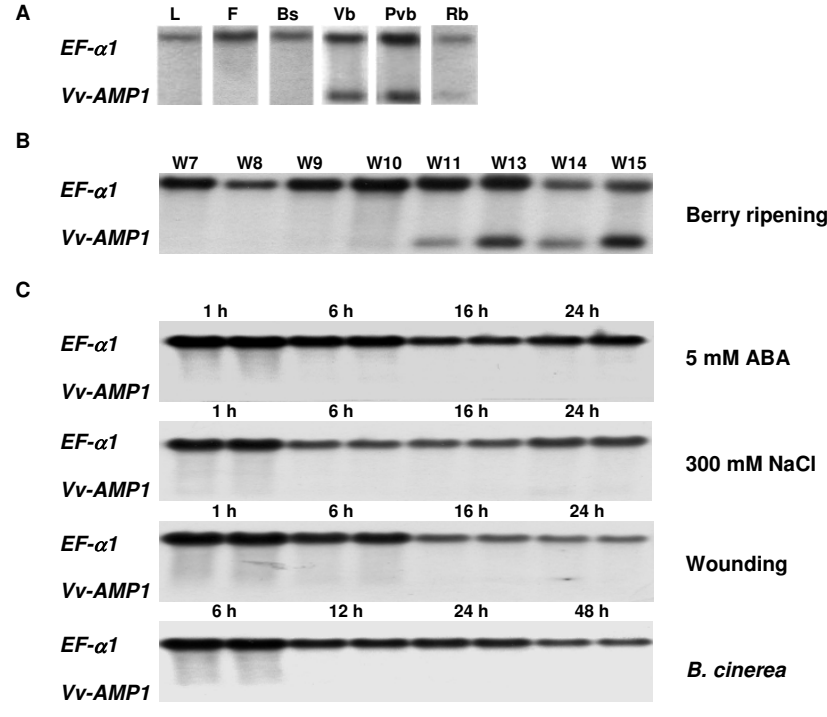

\section{Figure 7}

The expression profile of $V v-A M P I$ within the grapevine cultivar Pinotage. (A) Northern blot analysis of total RNA isolated from leaf $(\mathrm{L})$ and flower tissue $(F)$ as well as four berry developmental stages: Berry set (Bs), Véraison $(\mathrm{Vb})$, Post-véraison (Pvb), Ripe (Rb). (B) Induction of $V v$ AMPI by developmental regulation $(\mathbf{C})$. Biotic and abiotic induction studies were conducted on Pinotage leaf tissue. Time points indicate the time of tissue collection after the initiation of each induction experiment. Northern blot signals were detected by probing with a DIG labelled $V v-A M P I$ cDNA and a $V$. vinifera EF- $\alpha$ l probe as internal standard. The $V_{v}-A M P I$ signal hybridized at a molecular weight of $500 \mathrm{bp}$ and the internal standard at $2500 \mathrm{bp}$.

pathogens) and could not be included in this evaluation. Vv-AMP1 was especially effective against the causal agents of wilting disease, but also inhibited the necrotrophic Botrytis. Vv-AMP1 limited the fungal biomass of the test organisms, but did not induce typical morphological changes (under the conditions tested) in the treated cultures, classifying Vv-AMP1 as a non-morphogenic antifungal defensin peptide.

The inhibition profile of Vv-AMP1 is interesting and promising, both from the perspectives of general plant biotechnology, as well as understanding and manipulating grapevine defence specifically. The strong activity of Vv-AMP1 towards $V$. dahliae is of great interest in the engineering of disease resistant crops species. Vv-AMP1 is very active against $V$. dahliae, with particularly low $\mathrm{IC}_{50}$ values. A defensin peptide from Medicago sativa, alfAFP, has already showed great economical potential [62] by protecting potato against $V$. dahlia under field trial conditions. The activity of the peptide against grapevine pathogens still needs further evaluation, but preliminary
A
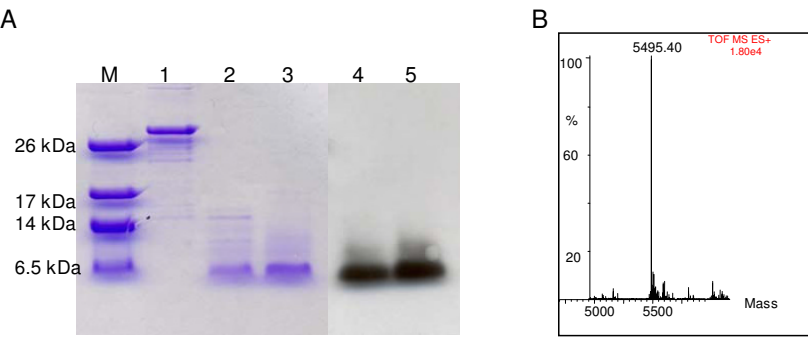

Figure 8

Size determination and Western blot analysis of the purified recombinant Vv-AMPI peptide. (A) SDS-

PAGE analysis of the GST-fusion protein before and after thrombin treatment; lane $M$, low molecular weight marker (Sigma, St Louis, USA); lane I GST-fusion protein, lane 2 and 3 purified $V_{v}$-AMPI peptide after thrombin digestion and cation exchange chromatography; lanes 4 and 5, Western blot analysis of Vv-AMPI. (B) Mass spectrometric analysis of recombinant $V_{v}$-AMPI after separation from the GST-tag using ion exchange chromatography.

inhibition analysis with a few pathogenic fungi that can be cultured in vitro yielded very promising results. Several of the grapevine trunk disease pathogens show strong sensitivity to the peptide in vitro (M. Tredoux, Institute for Wine Biotechnology, personal communication). Most of the economically important grapevine fungal pathogens require the plant host for growth and transgenic overexpression studies and whole plant infection assays are needed to determine the effect of the peptide on the these pathogens.

The observed activity of Vv-AMP1 was associated with alteration of fungal membrane permeability as indicated by the propidium iodide uptake assay and fluorescent microscopy (Figure 10). Previous studies have shown that plant defensins alter fungal membrane permeability, which is associated with a rapid uptake and efflux of $\mathrm{Ca}^{2+}$ and $\mathrm{K}^{+}[63,64]$. It remains to be elucidated whether $\mathrm{Vv}^{-}$ AMP1 used the same mechanism for the observed induction of membrane permeabilization.

Other questions that remain to be answered are the in planta stability of the peptide when overexpressed and the nature and degree of disease resistance that might be afforded by the peptide. The putative promoter of the $V v$ AMP1 gene has also been isolated from grapevine (results not shown) and might provide valuable insights into the regulation of this defensin.

\section{Conclusion}

$V v$-AMP1 encodes for a berry specific, developmentally regulated peptide with homology to the superfamily of plant defensins. Mature Vv-AMP1 is directed to the apo- 
A

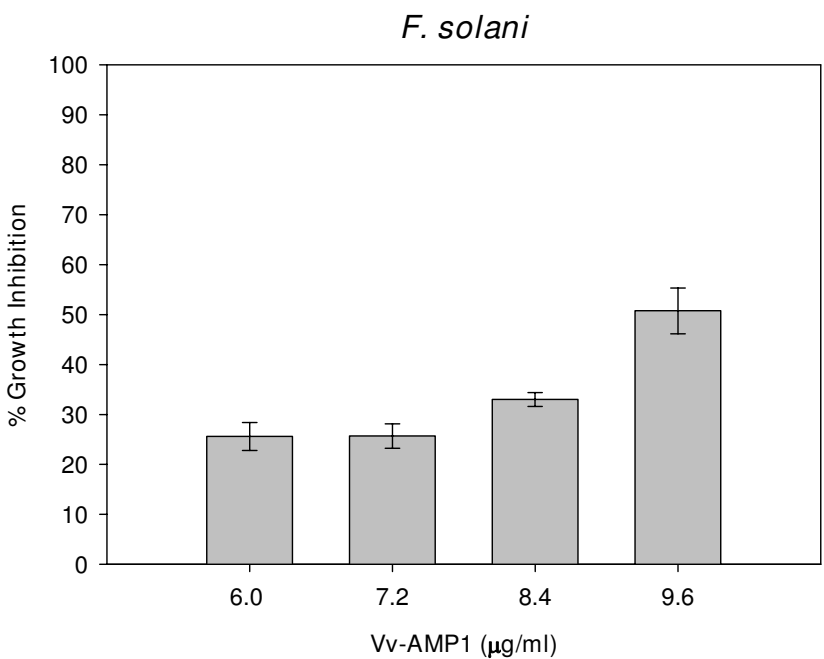

C

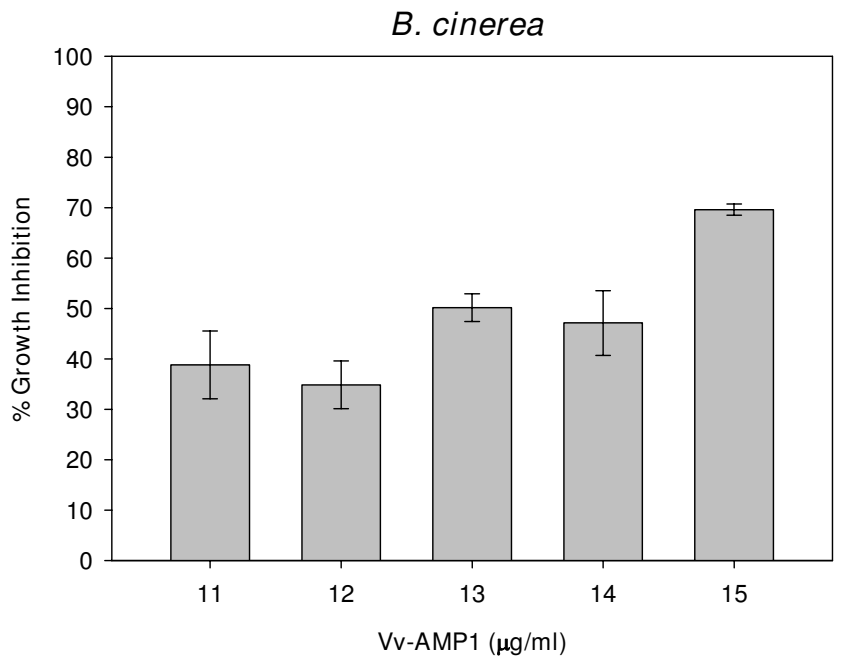

D
B
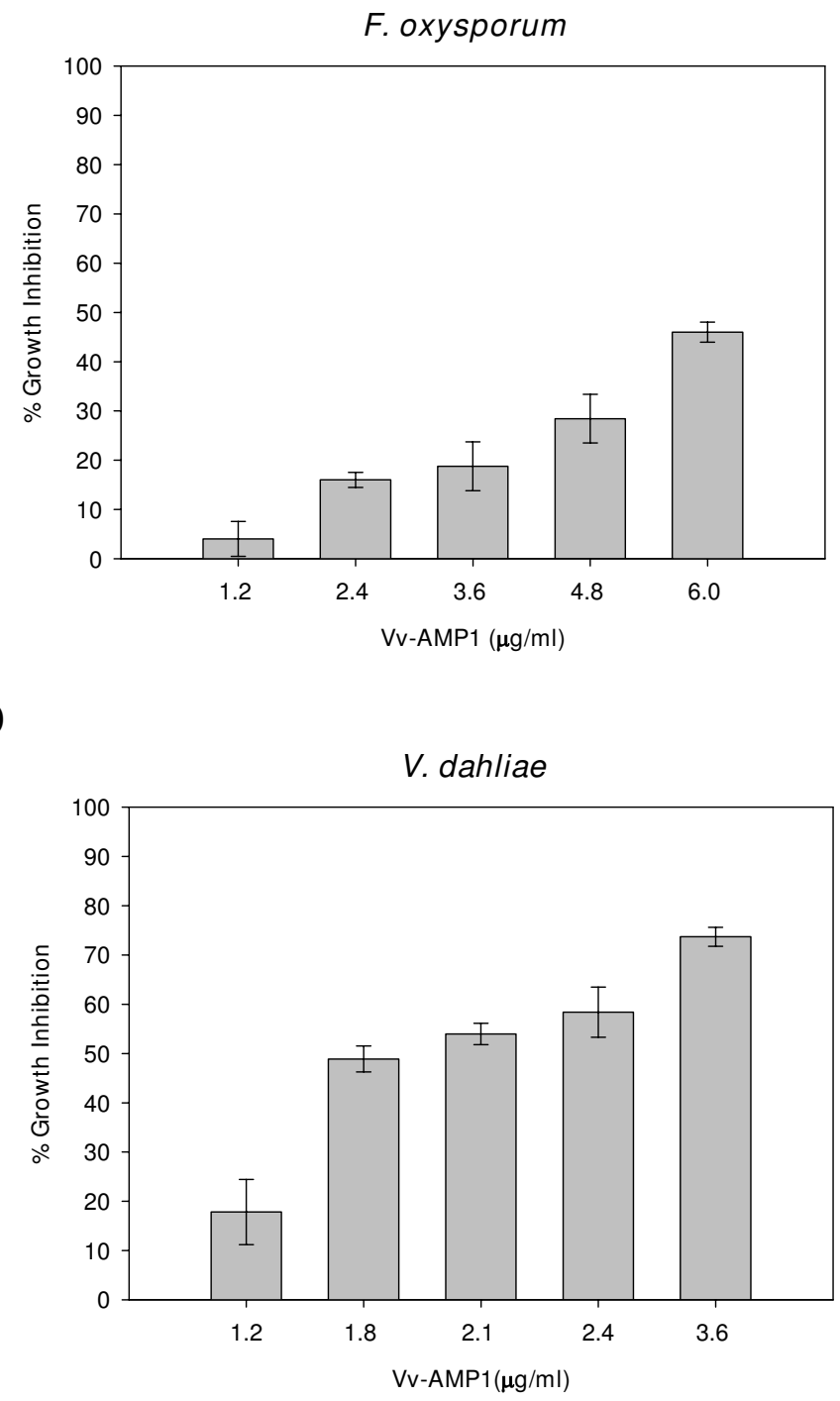

Figure 9

Antifungal activity of Vv-AMP I on a panel of plant pathogenic fungi. Microspectrophotometric readings were recorded every 24 hours and compared to the untreated fungal controls. The data is represented as a percentage of fungal growth as compared to the untreated control reactions with no peptide. The experiment was repeated three times and the standard deviation for each reaction was less than $5 \%$. Growth inhibition was determined after 48 hours of growth for the Fusarium and B. cinerea strains and after 72 hours for $V$. dahliae. The effect of $\mathrm{Vv}$-AMPI on the germination and growth of $F$. solani (A), F. oxysporum (B), B. cinerea (C) and V. dahliae (D) is shown.

plastic regions of the plant cell by a 30 amino acid signal peptide. Recombinant Vv-AMP1 showed a broad spectrum of antifungal activity at low concentrations against both necrotrophic and wilting disease causing fungi. $\mathrm{Vv}-$ AMP1 activity was classified as non-morphogenic and possibly associated with membrane permeabilization. The antifungal activities of the peptide are promising enough to merit further investigation of its potential in biotechnology approaches to increase fungal resistance in important crop species.

\section{Methods}

Plant materials and microbial strains

Escherichia coli strain DH5 $\alpha$ were used for all cloning experiments, while E. coli strain BL21 (Rosetta-gami pLys S) DE3 (Novagen (Madison, WI, USA) was used for recombinant protein production. Botrytis cinerea, Fusarium oxysporum and Fusarium solani were obtained from the Department of Plant Pathology (DPP), Stellenbosch University. Alternaria longipes (ATCC 26293), Fusarium oxysporum (ATCC 10913) and Verticillium dahliae (ATCC 96522) 
were obtained from the American Type Culture Collection. All of the above fungal strains were maintained on potato dextrose agar at $25^{\circ} \mathrm{C}$ until sporulation. Tobacco seeds were obtained from Lehle Seeds, Round Rock TX 78681, USA and tobacco plants were maintained on Murashige Skoog (MS) medium [65] in a growth room with a temperature of $25^{\circ} \mathrm{C}$ and a $16 \mathrm{~h}$ photoperiod.

\section{Primer design and defensin gene isolation}

The EST database of $V$. vinifera at TIGR [66] was screened using the BLAST algorithm. The database was screened with the $\gamma$-thionin sequence (PPT, gb|L27173.1) from Petunia inflata. Primers were designed from the EST clone TC69032 to recognize the complete coding sequence encoded within the EST.

Total RNA was isolated from $1 \mathrm{~g} V$. vinifera $\mathrm{cv}$. Pinotage root, leaf and berry tissue using a sodium perchlorate method [67]. cDNA was synthesized from total RNA using the SuperscriptIII cDNA synthesis kit (Invitrogen, Carlsbad, USA).

Genomic DNA was isolated from Pinotage leaves. Leaf tissue was collected, flash frozen in liquid nitrogen and ground to a fine powder. One gram of tissue was extracted with $10 \mathrm{ml}$ of extraction buffer according to an established method [68].

The genomic and cDNA isolated from $V$. vinifera $c v$. Pinotage were used as templates in PCR strategies to isolate possible Vitis defensin sequences. The primer set used was, forward primer Vitisdef-5' (5'-GGCTCGAGATGGAAGGGCTCTCAACGTT-3') together with the reverse primer Vitisdef-3' (5'-CCGGATCCTTAACAATGCTTAGTGC-3'). PCR products obtained were cloned into the pGEM-T easy vector (Promega Corporation, Madison, USA) and sent for sequencing. Sequences obtained were analyzed using the BLAST algorithm and clones showing homology to the defensin family were termed $V v$-AMPs.

\section{Southern blot analyses of Vv-AMP I}

Genomic DNA was isolated from $V$. vinifera $\mathrm{cv}$. Pinotage as described above. Pinotage genomic DNA was digested with KpnI, SpeI or XbaI and separated on a $0.8 \%$ [w/v] agarose TAE gel. After transfer to a nylon membrane [69], the membrane was probed with a DIG-labeled cDNA probe of $V v$-AMP1. Chemiluminescent detection was performed according to the DIG application manual for filter hybridization (Roche Diagnostics GmbH, Mannheim, Germany). Each hybridization signal represents a single copy of Vv-AMP1.

\section{Sequence analysis of Vv-AMPI within the Vitis genus} Germplasm of other Vitis species were obtained from the USDA-ARS National Clonal Germplasm Repository
(Davis, CA 95616, USA). These included genomic DNA for $V$. afganista, $V$. x andersonii, $V$. aestivallis, $V$. cinerea var. floridana, $V$. labrusca and Ampelopsis aconitifolia var. galabra. Genomic copies of $V v$-AMP1 were isolated from the various germplasms using the same PCR based strategy to isolate the genomic copy of $V v$-AMP1 from Pinotage. Isolated genes were cloned into the pGEM-T easy vector and sequenced. Genomic sequences obtained for the different Vitis species were analyzed with the AlignX software from the VectroNTI suite (Invitrogen, Carlsbad, USA) and final alignments were created in ClustalX [70].

\section{Expression pattern of Vv-AMP I}

Total RNA was isolated from $V$. vinifera cV. Pinotage leaves, flowers and the different developmental stages of berry ripening. Tissue was collected and ground in liquid nitrogen to a fine powder. One hundred mg tissue from leaf, flower and green berry tissue was extracted with 800 $\mu \mathrm{l}$ extraction buffer at $65^{\circ} \mathrm{C}(2 \%$ [w/v] CTAB, 2\% [w/v] PVP-40, $100 \mathrm{mM}$ Tris/HCl (pH 8.0), $25 \mathrm{mM}$ EDTA, $2.0 \mathrm{M}$ $\mathrm{NaCl}, 2 \%[\mathrm{v} / \mathrm{v}] \beta$-mercaptoethanol and $0.5 \mathrm{mg} / \mathrm{ml}$ Spermidine) for $5 \mathrm{~min}$ [71]. Total RNA from véraison to ripe berries was isolated with the sodium perchlorate method [67].

Total RNA was separated on a $1.2 \%[\mathrm{w} / \mathrm{v}]$ agarose formaldehyde gel (QIAGEN RNA/DNA handbook) and transferred to positively charged nylon membranes (Roche Diagnostics GmbH, Mannheim, Germany) [69]. Membranes were probed with a DIG-labeled $V v$-AMP1 cDNA probe and Elongation factor1 alpha $(E F-1 \alpha)$ gene from $V$. vinifera (TC65250) as internal standard. Pre-hybridization and hybridization were performed at $50^{\circ} \mathrm{C}$. Chemiluminescent detection was performed according to the DIG application manual for filter hybridization (Roche Diagnostics GmbH, Mannheim, Germany).

For analysis of the chemical induction of $V v-A M P 1, V$. vinifera leaves were floated on $300 \mathrm{mM} \mathrm{NaCl}$ or $5 \mathrm{mM}$ abscisic acid. Material was collected after 1, 6, 16 and 24 hours after each induction experiment and frozen in liquid nitrogen. Induction of $V v-A M P 1$ by wounding and B. cinerea infection was also assessed on leaf material. To evaluate the effect of wounding, leaves were subjected to mechanical damage and floated on distilled water in Petri dishes. Leaf material was collected and frozen in liquid nitrogen 1, 6, 16 and 24 hours after the initiation of the wounding experiment. $B$. cinerea infection was achieved by submerging leaves in a spore suspension of $50 \%$ grape juice containing 2000 spores/ml. After inoculation leaves were placed in Petri dishes under conditions of 100\% relative humidity and incubated at room temperature. Material was collected 6, 12, 24 and 48 hours after inoculation and frozen in liquid nitrogen. Detached pre-véraison stage berries were also subjected to the same inductions, as well 

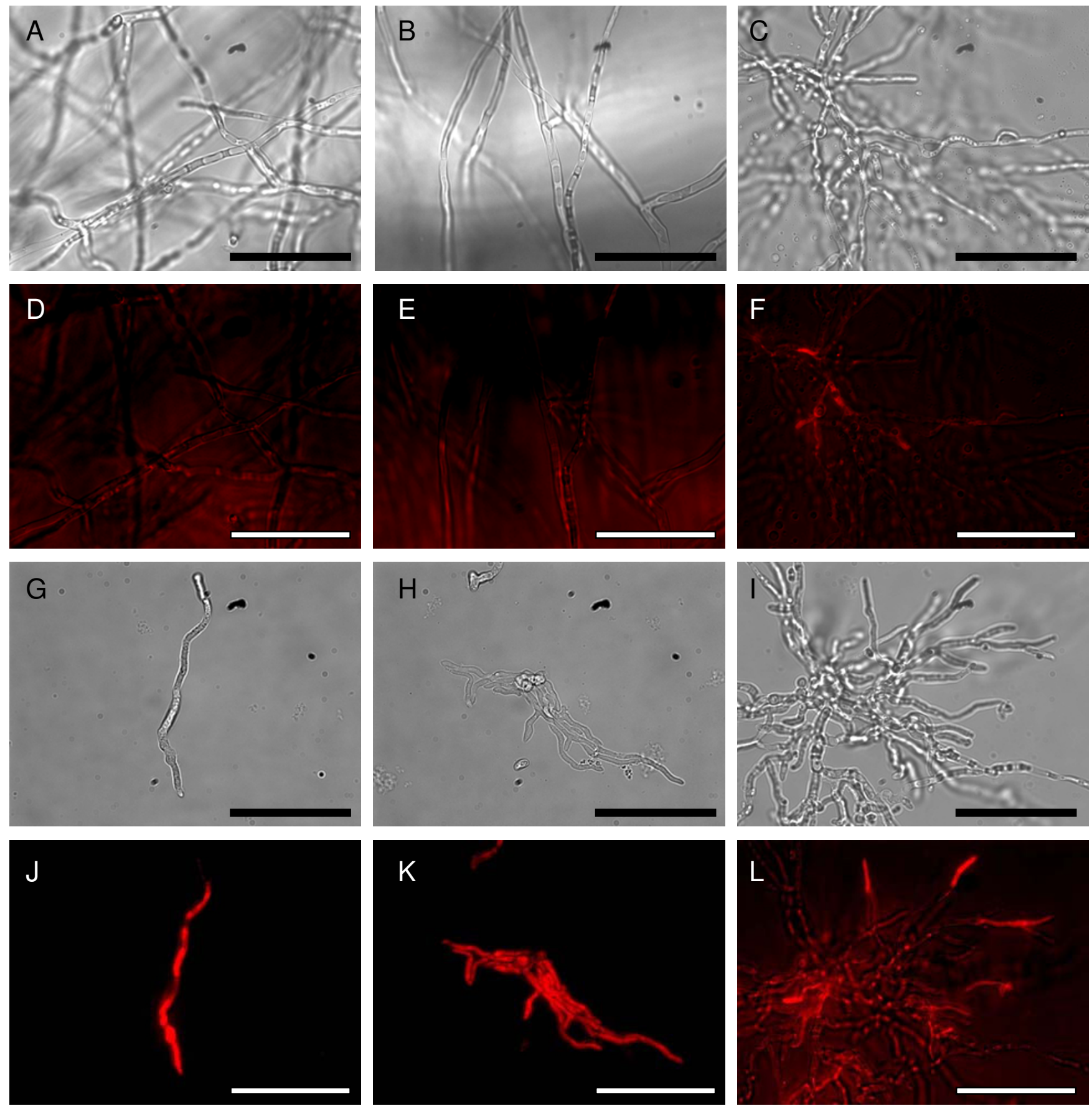

\section{Figure 10}

Fluorescent microscope analysis of Propidium lodide uptake during the membrane permeabilization assay. (AC), light microscope images and (D-F) Fluorescent images of untreated $F$. oxysporum, F. solani and V. dahliae hyphae respectively. (G-I), Light microscope images and (J-L) fluorescent images of Vv-AMPI treated F. oxysporum, F. solani and V. dahliae hyphae respectively. Fungi were grown for 40 hours in the presence of $V v$-AMPI at peptide concentrations of $6 \mu g / m l$ for $F$. solani, $9.6 \mu \mathrm{g} / \mathrm{ml}$ for F. oxysporum and $\mathrm{I} .8 \mu \mathrm{g} / \mathrm{ml}$ for V. dahliae. Afterwards fungal hyphae were stained with Propidium iodide for $10 \mathrm{~min}$, washed with IXPBS and subjected to fluorescent microscopic analysis. Bar $=50 \mu \mathrm{m}$ 
A The effect of 30 min temperature treatments on Vv-AMP1 activity

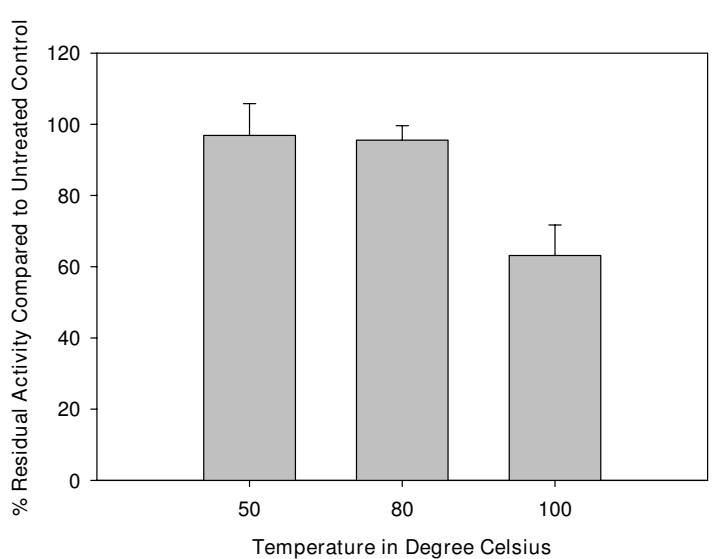

B

The effect of Prot K on Vv-AMP1 activity

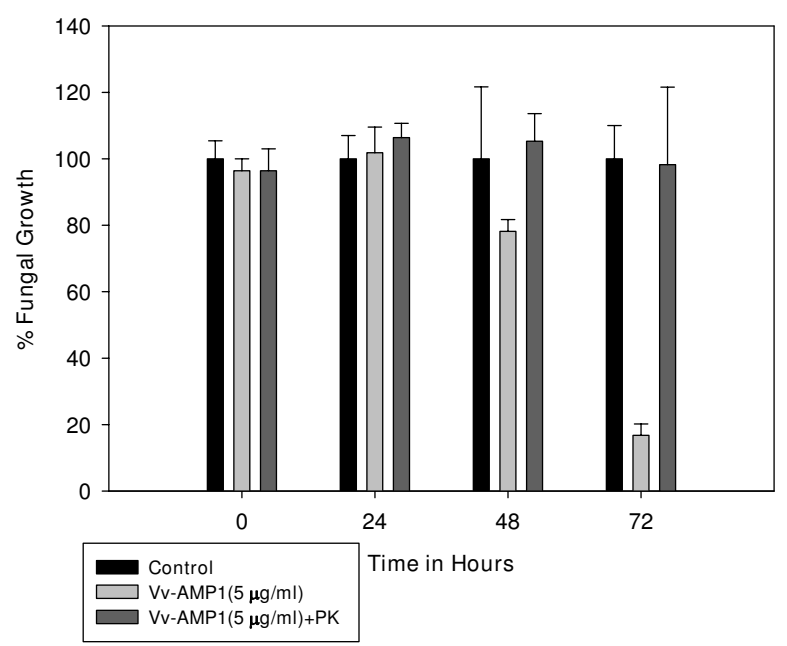

Figure I I

Stability assessment of Vv-AMPI. (A) Temperature stability of $\mathrm{V} v$-AMPI. After heat treatment the remaining antifungal activity of $\mathrm{Vv}$-AMPI was scored against the control with no heat treatment $\left(25^{\circ} \mathrm{C}\right)$. (B) Stability of $\mathrm{Vv}$-AMPI against proteinase $\mathrm{K}(\mathrm{PK})$. The antifungal activity of $\mathrm{Vv}-\mathrm{AMPI}$ (at a dose of $5 \mu \mathrm{g} / \mathrm{ml}$ ) was scored against $V$. dahliae after treatment with $100 \mu \mathrm{g} / \mathrm{ml}$ proteinase $\mathrm{K}$ at $37^{\circ} \mathrm{C}$ for $16 \mathrm{~h}$.

as to $10 \mathrm{mM}$ salicylic acid and $5 \mathrm{mM}$ jasmonic acid. All induction experiments were repeated three times, the material pooled and subjected to two separate RNA extractions. RNA isolation and Northern blot analysis were performed as described above.

\section{Bioinformatical analysis of the deduced amino acids sequence of Vv-AMP I}

The deduced amino acid sequence of $\mathrm{Vv}$-AMP1 was produced in VectorNTi and analyzed using the BLASTP algo- rithm. Homologous sequences identified were further aligned using ClustalX [70]. The deduced Vv-AMP1 sequence was also subjected to disulfide bridge analyses using DIpro [72]; secondary structure analysis as well homology modeling were done using the software package LOOPP@CBSU version 3.0 [73]. PDB files obtained were further analyzed using the software package VMD (Visual Molecular Dynamics) and final images were rendered using POV-Ray. Sub-cellular localization directed by the Vv-AMP1 signal peptide was predicted on the Proteome Analyst Specialized Sub-cellular Localization Server (PA-SUB) [74]. Peptide mass prediction was done with the Expasy tool, PEPTIDE-MASS [75].

\section{Confirming the subcellular localization directed by the $\mathrm{Vv}$ - AMPI signal peptide}

In an effort to confirm the sub-cellular targeting predicted by PA-SUB, the signal peptide from Vv-AMP1 was fused to the Green Fluorescent Protein (GFP) reporter protein. The signal peptide from $\mathrm{VV}$-AMP1 was isolated by PCR using the primer set Vitisdef-5' and Vitis SP-3' (5'-AAGCTTAGCCTCAGCCACCATCGG-3') and cloned into pGEMT easy vector to yield pGEM-VvSP. The signal peptide was excised from pGEM-VvSP with XhoI and HindIII and cloned into the restriction enzyme prepared plant expression vector pART27cassette, a pART27 vector [76] containing the expression cassette from pART7 cloned into the NotI sites of pART27. The construct was termed pART27-VvSP. A modified mGFP5 gene was prepared by PCR from the ABRC clone pLMNC92. The forward primer PIV2GFP5-5' (5'-CCAAGCTTGTAAGTTTCTGCTTCTACCTTTGA-3') and reverse primer PIV2GFP5-3' (5'GCCTCTAGATTATTTGTATAGTTCATCCATGC-3') were used to PCR the GFP sequence from the plasmid pLMNC92. This GFP sequence lacked the N-terminal endoplasmic reticulum signal peptide as well as a C-terminal HDEL ER retention signal. The PCR product was cloned into pGEM-T easy vector to yield pGEM-GFP5. The GFP fragment was excised from pGEM-GFP5 with HindIII and $X b a I$ and cloned into the restriction prepared pART27-VvSP vector to yield the plant expression vector pARTVvSP-GFP, which would allow for the expression of the $\mathrm{Vv}$-AMP signal peptide fused to GFP, under control of the constitutive $35 \mathrm{~S}$ cauliflower mosaic virus promoter. The pARTVvSP-GFP construct was transformed into Agrobacterium tumefaciens strain EHA105 via electroporation [77] and tobacco was transformed using a standard leaf disc method [78]. Plantlets were regenerated under kanamycin selection on MS medium and plantlets showing GFP fluorescence in their root system were identified by fluorescent emissions after GFP excitation on a dark reader (Clare Chemical Research, CO, USA). Hand sections were prepared from leaf petioles (untransformed controls as well as transgenic lines overexpressing GFP) and mounted in MS salt solution containing 40\% [v/v] 
glycerol. GFP localization was visualized under an Olympus IX 81 inverted microscope. GFP excitation was achieved at $470 \mathrm{~nm}$ and fluorescent images were captured using the GFP filter cube of the CelliR $\mathrm{R}^{\circledast}$ camera and software system (Olympus Soft Imaging Solutions $\mathrm{GmbH}$ ). All images captured were subjected to the CelliR ${ }^{\circledast}$ background noise reducing filters at an intensity setting of 7 .

\section{Recombinant production of $\mathbf{V} \mathbf{v}-\mathbf{A M P I}$}

The pGEX-2T system (Amersham Biosciences, NJ, USA) was used for the recombinant production of Vv-AMP1 in E. coli. This system would allow for the production of mature Vv-AMP1 peptide fused to a GST-tag. pGEM-VvAMP1 served as template to prepare the mature Vv-AMP1 sequence by PCR. This was achieved with the primer set 'Vv1-GST-5' (5'-GGCCGGATCCAGGACCTGTGAGAGTCAGAGCCACCG-3') and Vitdef-3'. The resulting product was cloned into the pGEM-T easy vector and termed pGEM-GSTVv1 mature. The mature fragment was digested from pGEM-GSTVv1 with BamHI and EcoRI and cloned into the BamHI and EcoRI prepared pGEX-2T vector. Positive clones were sequenced and termed pGEX-Vv1.

pGEX-Vv1 was transformed into the BL21 (Rosetta-gami pLysS) DE3 (Novagen Madison, WI, USA) and positive colonies were selected by plating onto LB agar containing $50 \mu \mathrm{g} / \mathrm{ml}$ ampicillin, $12.5 \mu \mathrm{g} / \mathrm{ml}$ tetracyclin, $15 \mu \mathrm{g} / \mathrm{ml}$ kanamycin sulphate and $34 \mu \mathrm{g} / \mathrm{ml}$ chloramphenicol. A single colony was inoculated into $5 \mathrm{ml} \mathrm{LB}$ medium with antibiotics and grown overnight at $37^{\circ} \mathrm{C}$. One $\mathrm{ml}$ preculture was inoculated into four $1 \mathrm{l}$ Erlenmeyer flasks containing $400 \mathrm{ml} \mathrm{LB}$ medium with antibiotics and grown at $37^{\circ} \mathrm{C}$ with continuous shaking until an $\mathrm{OD}_{600}$ of 0.7 . Expression of the GST-Vv1 fusion was induced with 0.4 mM IPTG for 5 hours at $22^{\circ} \mathrm{C}$.

Bacterial pellets were collected from each flask by centrifugation and resuspended in $5 \mathrm{ml}$ GST column binding buffer $\left(10 \mathrm{mM} \mathrm{Na}_{2} \mathrm{HPO}_{4}, 1.8 \mathrm{mM} \mathrm{KH}_{2} \mathrm{PO}_{4}, 2.7 \mathrm{mM} \mathrm{KCl}\right.$, $140 \mathrm{mM} \mathrm{NaCl}_{2}, \mathrm{pH} 7.6$ and $4 \mathrm{mM}$ PefaBloc from Roche Diagnostics GmbH, Mannheim, Germany) and frozen at $-80^{\circ} \mathrm{C}$. Cells were disrupted by repetitive freeze thaw cycles from liquid nitrogen to a $37^{\circ} \mathrm{C}$ water bath. Cell lysate was collected through centrifugation at $10000 \mathrm{rpm}$ and adjusted to $5 \mathrm{mM} \mathrm{MgCl}_{2}$. Lysate was treated with 10 units of DNase I (Roche Diagnostics GmbH, Mannheim, Germany) for $15 \mathrm{~min}$ at room temperature to reduce viscosity. Triton $\times 100$ was added to a final concentration of $1 \%(\mathrm{w} / \mathrm{v})$ and the bacterial cell lysate was cleared through centrifugation at $10000 \mathrm{rpm}$ for $15 \mathrm{~min}$ and passed through a $0.22 \mu \mathrm{M}$ filter.

Recombinant protein was batch purified with Glutathione agarose resin. A $2 \mathrm{ml}$ bed volume of Glutathione agarose4B (Sigma, St Louis, USA) was added to the fil- tered lysate and the recombinant peptide allowed to bind overnight on a rotor mixer. Unbound proteins were removed by washing twice with $10 \mathrm{ml}$ GST binding buffer, followed by two washes of $10 \mathrm{ml}$ of GST binding buffer containing $1 \%$ Triton $\times 100$ to remove unspecific bound proteins. Bound recombinant GST-Vv-AMP1 peptide was eluted with $10 \mathrm{ml}$ elution buffer (50 mM Tris-Cl, $\mathrm{pH}$ 8.0, $10 \mathrm{mM}$ reduced glutathione). The $\mathrm{N}$-terminal GST-tag was removed by thrombin digestion overnight at room temperature with 20 units of enzyme (Amersham Biosciences, NJ, USA). SDS-PAGE analysis was used to confirm the purity of the recombinant fusion protein after affinity chromatography and the complete removal of the N-terminal GST-tag by thrombin digestion.

The GST-tag was separated from mature Vv-AMP1 peptide using cation exchange chromatography on a SP sepharose column (Amersham Pharmacia Biotech). Samples containing the mature Vv-AMP1 peptide were pooled and loaded onto a Strata C8 Solid Phase Extraction column (Phenomenex, Torrance, CA, USA). Bound peptide was desalted by washing with 5 column volumes of $\mathrm{dH}_{2} \mathrm{O}$ containing $0.1 \%[\mathrm{v} / \mathrm{v}]$ TFA and eluted with $5 \mathrm{ml}$ of $60 \%$ $[\mathrm{v} / \mathrm{v}]$ acetonitrile containing $0.1 \%$ [v/v] TFA. Eluted peptide was freeze-dried, dissolved in distilled water at a final concentration of $100 \mu \mathrm{g} / \mathrm{ml}$ and stored at $-20^{\circ} \mathrm{C}$.

\section{Size determination and identification of heterologous $V v$ - AMPI}

To confirm the purification of the Vv-AMP1-GST fusion protein and evaluate the cleavage of the GST-tag from VvAMP1, $2 \mu \mathrm{g}$ purified protein was separated on a $15 \%[\mathrm{w} /$ v] Tris-Tricine gel [79]. After separation the gel was microwave stained in staining solution (Coomassie R250 in $50 \%$ [v/v] ethanol, $10 \%$ [v/v] acetic acid). The gel was destained with $12.5 \%[\mathrm{v} / \mathrm{v}]$ isopropanol and $12 \%[\mathrm{v} / \mathrm{v}]$ acetic acid. The exact size of mature Vv-AMP1 peptide samples was determined by LC/MS analysis on a Waters API Q-TOF Ultima instrument.

Identification of the peptide was achieved by peptide mass fingerprinting. Forty five $\mu \mathrm{g}$ recombinant Vv-AMP1 peptide was digested with the ProteoExtract ${ }^{\text {tm }}$ all-in-one trypsin digest kit (Calbiochem, La Jolla, CA, USA) and subjected to LC/MSMS analysis on a Waters API Q-TOF Ultima instrument. The resulting peaks were analyzed with the Expasy program FindPep [75].

\section{Preparation of antibody and immunoblotting}

Polyclonal antibodies against Vv-AMP1 were produced in mice by immunizing three mice with $300 \mu \mathrm{g}$ of the GSTVv-AMP1 fusion protein in Freund's complete conjugate. Two booster injections consisting of $100 \mu \mathrm{g}$ protein in Freund's complete conjugate were given at 2 week intervals 
and a final injection with $100 \mu \mathrm{g}$ purified Vv-AMP1 was given 2 weeks before the terminal bleed.

Western blot analysis was conducted on $400 \mathrm{ng}$ purified Vv-AMP1. The peptide was separated on a $15 \%(\mathrm{w} / \mathrm{v})$ Tristricine gel [79] together with a low molecular weight marker (Sigma, St Louis, USA). One half of the gel was stained with Coomassie R250 and the other half electroblotted to a PVDF membrane (BioRad, Hercules, CA, USA). The membrane was blocked for 3 hours in blocking buffer (phosphate buffered saline, $0.1 \%[\mathrm{w} / \mathrm{v}]$ Tween 20 and 5\% $[\mathrm{w} / \mathrm{v}]$ skim milk) before incubating overnight in a 1:500 dilution of primary antibody prepared in blocking buffer. Detection of Vv-AMP1 was achieved with anti-mouse IgG secondary antibody and the ECL chemiluminecent system according to Amersham Biosciences, NJ, USA.

\section{Antimicrobial activity of recombinant $\mathrm{Vv-AMPI}$}

Quantitative antifungal activity of Vv-AMP1 was measured by microspectrophotometry [80]. The assay was preformed in a 96-well microtiter plate (Bibby Sterilin Ltd, Stone, Staffs, UK), where each well contained $100 \mu \mathrm{l}$ half strength Potato Dextrose Broth (PDB) with 2000 fungal spores and purified Vv-AMP1 peptide of $1-20 \mu \mathrm{g} / \mathrm{ml}$, respectively. Control reactions contained no peptide. Plates were incubated in the dark at $25^{\circ} \mathrm{C}$ for 3 days. Microspectrophotometric readings were taken every 24 hours at $A_{595}$. All readings were corrected by subtracting the time zero readings from the time 24,48 and 72 hour readings. Vv-AMP1 activity was scored after 48 hours and expressed in terms of \% growth inhibition. Percentage growth inhibition is defined as $100 \times$ the ratio of the corrected $A_{595}$ of the control minus the corrected $A_{595}$ of the sample over the corrected $A_{595}$ of the control. Each activity assay was independently repeated three times with three technical repeats per measurement. Microscope images were also collected directly from the antifungal assays with an Olympus IX70 inverted microscope. Images were captured with the Analysis ${ }^{\circledast}$ software (Olympus Soft Imaging Solutions GmbH - results not shown).

The ability of Vv-AMP1 to cause fungal membrane permeabilization was assessed using a Propidium Iodide (PI) uptake assay [81], conducted on F. oxysporum, F. solani and $V$. dahliae. The permeabilization assay consisted of $200 \mu \mathrm{l}$ half-strength PDB containing fungal spores $\left(2 \times 10^{4}\right.$ spores $/ \mathrm{ml}$ ) and Vv-AMP1 peptide at concentrations of 6 $\mu \mathrm{g} / \mathrm{ml}$ for F. solani, $9.6 \mu \mathrm{g} / \mathrm{ml}$ for F. oxysporum and $1.8 \mu \mathrm{g} /$ $\mathrm{ml}$ for the $V$. dahliae isolate. Fungal strains were incubated at $25^{\circ} \mathrm{C}$ in the presence of Vv-AMP1 for 40 hours. Control samples contained no Vv-AMP1. After incubation the samples were washed with $1 \mathrm{xPBS}$ and stained for $10 \mathrm{~min}$ in PI staining solution ( $25 \mu \mathrm{g} / \mathrm{ml}$ PI in PBS). Stained samples were washed twice with $1 \times$ PBS and viewed under an Olympus IX 81 inverted fluorescent microscope. Images were capture with the Celli $\mathrm{R}^{\circledast}$ digital camera and software system (Olympus Soft Imaging Solutions $\mathrm{GmbH}$ ). The presence of fluorescence is indicative of a compromised fungal membrane.

\section{Heat stability assessment and proteinaceous nature of recombinant Vv-AMPI}

The stability of the heterologous Vv-AMP1 peptide was assessed by an antifungal assay as described above. The heat stability of the peptide was assessed at a final peptide concentration of $20 \mu \mathrm{g} / \mathrm{ml}$ against $B$. cinerea spores, with the peptide being pretreated at $25^{\circ} \mathrm{C}, 50^{\circ} \mathrm{C}, 80^{\circ} \mathrm{C}$ and $100^{\circ} \mathrm{C}$ for $30 \mathrm{~min}$, before commencing with the antifungal assay. The activity of $\mathrm{Vv}-\mathrm{AMP} 1$ was scored against the control reaction conducted at $25^{\circ} \mathrm{C}$. Vv-AMP1 peptide was also subjected to a proteinase stability assay. $\mathrm{Vv}$ AMP1 was treated with proteinase $\mathrm{K}(100 \mu \mathrm{g} / \mathrm{ml})$ at $37^{\circ} \mathrm{C}$ for 16 hours. After digestion Vv-AMP1 was subjected to an antifungal assay against $V$. dahliae at a final concentration of $5 \mu \mathrm{g} / \mathrm{ml}$. The activity of $\mathrm{Vv}$-AMP1 was scored against a control reaction containing proteinase $\mathrm{K}(100 \mu \mathrm{g} / \mathrm{ml})$, but without any Vv-AMP1 peptide added. All the above mentioned assays were done in triplicate.

\section{Authors' contributions}

MAV supervised the work and helped with conceptual design and manuscript preparation as well as final data analysis. AdB performed conceptual and experimental design and was responsible for all the research procedures.

\section{Acknowledgements}

We would like to thank the following individuals for their support and contributions as indicated: Dr M Stander from the Central Analytical Facility at Stellenbosch University for the LCIMS results; Dr E Pool for antibody production; Dr Rob Smith and Mr Ben Loos for help with the fluorescent microscopical analysis; Dr M Rautenbach for her valuable advice on the purification of recombinant Vv-AMPI. The work was financially supported by the National Research Foundation, THRIP, Winetech and Deciduous Fruit Producer Trust.

\section{References}

I. Dixon R, Harrison M, Lamb C: Early events in the activation of plant defense responses. Annu Review Phytopath 1994, 32:479-50 I.

2. Kuc J: Antifungal compounds in plants. In Phytochemical resources for medicine and agriculture Edited by: Nigg HN, siegler D. Plenum Press, New york, NY; 1992:159-184.

3. Kuc J: Compounds from plants that regulate or participate in disease resistance. Boioactive compounds from plants Wiley, Chichester (Ciba Foundation Symposium 154) 1990:213-228.

4. Osbourn AE: Preformed Antimicrobial Compounds and Plant Defense against Fungal Attack. Plant Cell 1996, 8(10): $|82|-|83|$.

5. Prost I, Dhondt S, Rothe G, Vicente J, Rodriguez MJ, Kift N, Carbonne F, Griffiths G, Esquerre-Tugaye MT, Rosahl S, Castresana C, Hamberg $M$, Fournier J: Evaluation of the antimicrobial activities of plant oxylipins supports their involvement in defense against pathogens. Plant Physiol 2005, I39(4): 1902-1913.

6. van Loon LC, Rep M, Pieterse CM: Significance of inducible defense-related proteins in infected plants. Annu Rev Phytopathol 2006, 44: I35-162. 
7. Bohlmann H, Apel K: Thionins. Annu Rev Plant Physiol Plant Mol Biol I991, 42:227-240.

8. Lay FT, Anderson MA: Defensins-components of the innate immune system in plants. Curr Prot Pept Sci 2005, 6(I):85-10I.

9. Stec B: Plant thionins - the structural perspective. Cell Mol Life Sci 2006, 63( I 2): I370-I385.

10. Thomma BP, Cammue BP, Thevissen K: Plant defensins. Planta 2002, 2 I 6(2): 193-202.

II. Broekaert W, Terras F, Cammue B, Osborn R: Plant defensins: novel antimicrobial peptides as components of the host defense system. Plant Physiol 1995, I 08:1353-1358.

12. Florack $D$, Stiekema W: Thionins: properties, possible biological roles and mechanisms of actions. Plant Mol Biol 1994, 26:25-37.

13. Garcia-Olmedo F, Molina A, Alamillo JM, Rodriguez-Palenzuela P: Plant defense peptides. Biopolymers 1998, 47(6):479-49|.

14. Osborn R, De Samblanx G, Thevissen K, Goderis I, Torrekens S, Van Leuven $F$, Attenborough S, Rees S, Broekaert W: Isolation and characterisation of plant defensins from seeds of Asteraceae, Fabaceae, Hippocastanaceae and Saxifragaceae. FEBS Lett 1995, 368:257-262.

I5. Terras FR, Torrekens S, Van Leuven F, Osborn RW, Vanderleyden J, Cammue BP, Broekaert WF: A new family of basic cysteine-rich plant antifungal proteins from Brassicaceae species. FEBS Lett 1993, 3 I 6(3):233-240.

16. Aerts A, Thevissen K, Bresseleers S, Sels J, Wouters P, Cammue B, François I: Arabidopsis thaliana plants expressing human beta-defensin-2 are more resistant to fungal attack: functional homology between plant and human defensins. Plant Cell Rep 2007, 26(8): I391-1398.

17. Aerts A, Thevissen K, Bresseleers S, Wouters P, Cammue B, Francois I: Heterologous production of human beta-defensin-2 in Arabidopsis thaliana. Commun Agric Appl Biol Sci 2005, 70(2):5I-55

18. Castro MS, Fontes W: Plant defense and antimicrobial peptides. Protein Pept Lett 2005, I 2(I): I3-18.

19. Almeida MS, Cabral KM, Kurtenbach E, Almeida FC, Valente AP. Solution structure of Pisum sativum defensin I by high resolution NMR: plant defensins, identical backbone with different mechanisms of action. J Mol Biol 2002, 3 I 5(4):749-757.

20. Fant F, Vranken W, Broekaert W, Borremans F: Determination of the three-dimensional solution structure of Raphanus sativus antifungal protein I by IH NMR. I Mol Biol 1998, 279(I):257-270.

21. Janssen BJ, Schirra HJ, Lay FT, Anderson MA, Craik DJ: Structure of Petunia hybrida defensin I, a novel plant defensin with five disulfide bonds. Biochemistry 2003, 42(27):82|4-8222.

22. Liu YJ, Cheng CS, Lai SM, Hsu MP, Chen CS, Lyu PC: Solution structure of the plant defensin VrDI from mung bean and its possible role in insecticidal activity against bruchids. Proteins 2006, 63(4):777-786.

23. Terras FR, Eggermont K, Kovaleva V, Raikhel NV, Osborn RW, Kester A, Rees SB, Torrekens S, Van Leuven F, Vanderleyden J, Cammue B, Broekaert W: Small cysteine-rich antifungal proteins from radish: their role in host defense. Plant Cell 1995, 7(5):573-588.

24. Aerts AM, Francois IE, Bammens L, Cammue BP, Smets B, Winderickx J. Accardo S, De Vos DE, Thevissen K: Level of M(IP)2C sphingolipid affects plant defensin sensitivity, oxidative stress resistance and chronological life-span in yeast. FEBS Lett 2006, 580(7): 1903-1907.

25. Im YJ, Idkowiak-Baldys J, Thevissen K, Cammue BP, Takemoto JY: IPT I-independent sphingolipid biosynthesis and yeast inhibition by syringomycin $E$ and plant defensin DmAMPI. FEMS Microbiol Lett 2003, 223(2): 199-203.

26. Thevissen $K$, Cammue BP, Lemaire K, Winderickx J, Dickson RC, Lester RL, Ferket KK, Van Even F, Parret AH, Broekaert WF: A gene encoding a sphingolipid biosynthesis enzyme determines the sensitivity of Saccharomyces cerevisiae to an antifungal plant defensin from dahlia (Dahlia merckii). Proc Natl Acad Sci USA 2000, 97(I 7):953I-9536.

27. Thevissen K, Ferket KK, Francois IE, Cammue BP: Interactions of antifungal plant defensins with fungal membrane components. Peptides 2003, 24(I I): I705-I7I2.

28. Thevissen K, Idkowiak-Baldys J, Im YJ, Takemoto J, Francois IE, Ferke KK, Aerts AM, Meert EM, Winderickx J, Roosen J, Cammue BPA SKNI, a novel plant defensin-sensitivity gene in Saccharomy- ces cerevisiae, is implicated in sphingolipid biosynthesis. FEBS Lett 2005, 579(9): 1973-1977.

29. Thevissen K, Osborn RW, Acland DP, Broekaert WF: Specific binding sites for an antifungal plant defensin from Dahlia (Dahlia merckii) on fungal cells are required for antifungal activity. Mol Plant Microbe Interact 2000, I 3(I):54-6I.

30. Thevissen K, Osborn RW, Acland DP, Broekaert WF: Specific, high affinity binding sites for an antifungal plant defensin on Neurospora crassa hyphae and microsomal membranes. I Biol Chem 1997, 272(5I):32I76-32I8I.

31. Thevissen K, Warnecke DC, Francois IE, Leipelt M, Heinz E, Ott C, Zahringer U, Thomma BP, Ferket KK, Cammue BP: Defensins from insects and plants interact with fungal glucosylceramides. J Biol Chem 2004, 279(6):3900-3905.

32. Bloch C Jr, Richardson M: A new family of small (5 kD) protein inhibitors of insect $\alpha$-amylase from seeds of sorghum (Sorghum bicolor (L.) Moench) have sequence homologies with wheat $\gamma$-purothionins. FEBS Lett 1991, 279: I01-104.

33. Melo FR, Rigden DJ, Franco OL, Mello LV, Ary MB, Grossi de Sa MF, Bloch C Jr: Inhibition of trypsin by cowpea thionin: characterization, molecular modeling, and docking. Proteins 2002 , 48(2):3| |-3। 9

34. Mirouze $M$, Sels J, Richard $O$, Czernic $P$, Loubet $S$, Jacquier A, Francois IEJA, Cammue BPA, Lebrun M, Berthomieu P, Marques L: A putative novel role for plant defensins: a defensin from the zinc hyper-accumulating plant, Arabidopsis halleri, confers zinc tolerance. Plant J 2006, 47(3):329-342.

35. Wong $\mathrm{JH}, \mathrm{Ng} \mathrm{TB}$ : Gymnin, a potent defensin-like antifungal peptide from the Yunnan bean (Gymnocladus chinensis Baill). Peptides 2003, 24(7):963-968.

36. Wong $\mathrm{JH}, \mathrm{Ng}$ TB: Sesquin, a potent defensin-like antimicrobia peptide from ground beans with inhibitory activities toward tumor cells and HIV-I reverse transcriptase. Peptides 2005 , 26(7): II20-II26.

37. Wong $\mathrm{J}, \mathrm{Ng} \mathrm{TB}$ : Vulgarinin, a broad-spectrum antifungal peptide from haricot beans (Phaseolus vulgaris). Internat j Biochem Cell Biol 2005, 37(8): I626.

38. Almeida MS, Cabral KM, Zingali RB, Kurtenbach E: Characterization of two novel defense peptides from pea (Pisum sativum) seeds. Arch Biochem Biophys 2000, 378(2):278-286.

39. Chen GH, Hsu MP, Tan CH, Sung HY, Kuo CG, Fan MJ, Chen HM, Chen S, Chen CS: Cloning and characterization of a plant defensin VaDI from azuki bean. J Agric Food Chem 2005, 53(4):982-988

40. Chen KC, Lin CY, Chung MC, Kuan CC, Sung HY, S. TSC, Kuo CG Chen CS: Cloning and characterization of a cDNA encoding an antimicrobial protein from mung bean seeds. Bot Bull Acad $\operatorname{Sin} 2002,43: 251-259$

4I. Osborn RW, De Samblanx GW, Thevissen K, Goderis I, Torrekens S, Van Leuven F, Attenborough S, Rees SB, Broekaert WF: Isolation and characterisation of plant defensins from seeds of Asteraceae, Fabaceae, Hippocastanaceae and Saxifragaceae. FEBS Lett 1995, 368(2):257-262

42. Song X, Wang J, Wu F, Li X, Teng M, Gong W: cDNA cloning, functional expression and antifungal activities of a dimeric plant defensin SPE I 0 from Pachyrrhizus erosus seeds. Plant Mol Biol 2005, 57(I): I3-20

43. Song X, Zhou Z, Wang J, Wu F, Gong W: Purification, characterization and preliminary crystallographic studies of a novel plant defensin from Pachyrrhizus erosus seeds. Acta Crystallogr D Biol Crystallogr 2004, 60(Pt 6): | | 2 | - | | 24.

44. Kragh KM, Nielsen JE, Nielsen KK, Dreboldt S, Mikkelsen JD: Characterization and localization of new antifungal cysteine-rich proteins from Beta vulgaris. Mol Plant Microbe Interact 1995 , 8(3):424-434

45. Karunanandaa B, Singh A, Kao TH: Characterization of a predominantly pistil-expressed gene encoding a gammathionin-like protein of Petunia inflata. Plant Mol Biol 1994, 26(I):459-464.

46. Lay FT, Brugliera F, Anderson MA: Isolation and properties of floral defensins from ornamental tobacco and petunia. Plant Physiol 2003, I 3 I (3): I 283-1293.

47. Park HC, Kang YH, Chun HJ, Koo JC, Cheong YH, Kim CY, Kim MC Chung WS, Kim JC, Yoo JH, Koo YD, Koo SC, Lim CO, Lee SY, Cho MJ: Characterization of a stamen-specific cDNA encoding a 
novel plant defensin in Chinese cabbage. Plant Mol Biol 2002, 50(I):59-69.

48. Tregear JW, Morcillo F, Richaud F, Berger A, Singh R, Cheah SC Hartmann C, Rival A, Duval Y: Characterization of a defensin gene expressed in oil palm inflorescences: induction during tissue culture and possible association with epigenetic somaclonal variation events. J Exp Bot 2002, 53(373): I387-I396.

49. Urdangarin MC, Norero NS, Broekaert WF, de la Canal L: A defensin gene expressed in sunflower inflorescence. Plant Physiol Biochem 2000, 38(3):253-258.

50. Moreno M, Segura A, Garcia-Olmedo F: Pseudothionin-StI, a potato peptide active against potato pathogens. Eur J Biochem 1994, 223:135-139.

5I. Meyer B, Houlne G, Pozueta-Romero J, Schantz ML, Schantz R: Fruitspecific expression of a defensin-type gene family in bell pepper. Upregulation during ripening and upon wounding. Plant Physiol 1996, I I 2(2):615-622.

52. Oh BJ, Ko MK, Kostenyuk I, Shin B, Kim KS: Coexpression of a defensin gene and a thionin-like via different signal transduction pathways in pepper and Colletotrichum gloeosporioides interactions. Plant $\mathrm{Mol}$ Biol I999, 4I(3):3। 3-3I9.

53. Wisniewski ME, Bassett CL, Artlip TS, Webb RP, Janisiewicz WJ, Norelli JL, Goldway M, Droby S: Characterization of a defensin in bark and fruit tissues of peach and antimicrobial activity of a recombinant defensin in the yeast, Pichia pastoris. Physiol Plant 2003, I I 9(4):563-572.

54. Ahn IP, Park K, Kim CH: Rhizobacteria-induced resistance perturbs viral disease progress and triggers defense-related gene expression. Mol Cells 2002, 13(2):302-308.

55. de Zélicourt A, Letousey P, Thoiron S, Campion C, Simoneau P, Elmorjani $K$, Marion D, Simier P, Delavault P: Ha-DEFI, a sunflower defensin, induces cell death in Orobanche parasitic plants. Planta 2007, 226(3):591-600.

56. Hanks JN, Snyder AK, Graham MA, Shah RK, Blaylock LA, Harrison MJ, Shah DM: Defensin gene family in Medicago truncatula: structure, expression and induction by signal molecules. Plant Mol Biol 2005, 58(3):385-399.

57. Koike M, Okamoto T, Tsuda S, Imai R: A novel plant defensin-like gene of winter wheat is specifically induced during cold acclimation. Biochem Biophys Res Commun 2002, 298(I):46-53.

58. Manners JM, Penninckx IA, Vermaere K, Kazan K, Brown RL, Morgan A, Maclean DJ, Curtis MD, Cammue BP, Broekaert WF: The promoter of the plant defensin gene PDFI.2 from Arabidopsis is systemically activated by fungal pathogens and responds to methyl jasmonate but not to salicylic acid. Plant Mol Biol 1998 , 38(6): $107 \mid-1080$

59. Heuvel KJ van den, Hulzink JM, Barendse GW, Wullems GJ: The expression of tgas II8, encoding a defensin in Lycopersicon esculentum, is regulated by gibberellin. J Exp Bot 200I, 52(360): I $427-1436$.

60. Moran PJ, Thompson GA: Molecular responses to aphid feeding in Arabidopsis in relation to plant defense pathways. Plant Physiol 200I, I 25(2): 1074-1085.

61. Symons GM, Davies C, Shavrukov Y, Dry IB, Reid JB, Thomas MR: Grapes on steroids. Brassinosteroids are involved in grape berry ripening. Plant Physiol 2006, I 40(I):I50-I58.

62. Gao AG, Hakimi SM, Mittanck CA, Wu Y, Woerner BM, Stark DM, Shah DM, Liang J, Rommens CM: Fungal pathogen protection in potato by expression of a plant defensin peptide. Nat Biotechnol 2000, I 8(1 2): I |307-1310.

63. Thevissen K, Ghazi A, De Samblanx GW, Brownlee C, Osborn RW, Broekaert WF: Fungal membrane responses induced by plant defensins and thionins. J Biol Chem 1996, 27 I(25): I 50 I 8-I 5025.

64. Thevissen K, Terras FR, Broekaert WF: Permeabilization of fungal membranes by plant defensins inhibits fungal growth. Appl Environ Microbiol 1999, 65( I 2):545 I-5458.

65. Murashige T, Skoog F: A revised medium for rapid growth and bio assays with tobacco tissue cultures. Plant Physiol 1962, 15:473-497.

66. The Institute for Genomic Research [http://www.tigr.org]

67. Davies C, Robinson SP: Sugar accumulation in grape berries (Cloning of two putative vacuolar invertase CDNAs and their expression in grapevine tissues). Plant Physiol 1996, III(I):275-283
68. Steenkamp J, Wild I, Lourens A, van Helden P: Improved method for DNA extraction from Vitis vinifera. Am J Enol Vitic 1994, 45(I): $102-106$

69. Sambrook J, Fitsch EF, T M: Molecular cloning: A laboratory manual. New York, Cold Spring Harbor Press 1989.

70. Thompson JD, Gibson TJ, Plewniak F, Jeanmougin F, Higgins DG: The ClustalX windows interface: flexible strategies for multiple sequence alignment aided by quality analysis tools. Nucl Acids Res 1997, 25:4876-4882.

7I. Chang S, Puryear J, Cairney J: A simple and efficient method for isolating RNA from pine trees. Plant Mol Biol Rep 1993, II:113-116.

72. Institute for Genomics and Bioinformatics [http:// www.igb.uci.edu]

73. CBSU Web Computing Resources [http://cbsuapps.tc.cor nell.edu/loopp.aspx]

74. Proteome Analyst Specialized Subcellular Localization Server [http://www.cs.ualberta.ca/\%7Ebioinfo/PA/Sub/index.html]

75. Expasy proteomics tools [http://us.expasy.org/tools/]

76. Gleave AP: A versatile binary vector system with a T-DNA organisational structure conductive to efficient integration of cloned DNA into the plant genome. Plant Mol Biol 1992, 20:1203-I 207.

77. Mattanovich D, Ruker F, da Camara Machado A, Laimer M, Regner F, Steinkeliner H, Himmler G, Katinger H: Efficient transformation of Agrobacterium spp. by eletroporation. Nucl Acids Res 1989, I7(16):6747.

78. Horsch R, Fry J, Hofmann N, Eichhlotz D, Rogers S, Fraylet R: A simple and general method for transferring genes into plants. Science 1985, 227(469I): |229-1231.

79. Schagger H, von Jagow G: Tricine-sodium dodecyl sulfate-polyacrylamide gel electrophoresis for the separation of proteins in the range from I to $100 \mathrm{kDa}$. Anal Biochem 1987, 166:368-379.

80. Broekaert W, Terras F, Cammue B, Vandereyden J: An automated quantitive assay for fungal growth inhibition. FEMS Microbiol lett 1990, 69:55-60.

8I. Gangwar M, Cole R, Ramani R, Sheehan D, Chaturvedi V: Application of fluorescent probes to study structural changes in Aspergillus fumigatus exposed to amphotericin B, itraconazole, and voriconazole. Mycopathologia 2006, I62(2): 103-109.

Publish with Biomed Central and every scientist can read your work free of charge

"BioMed Central will be the most significant development for disseminating the results of biomedical research in our lifetime. "

Sir Paul Nurse, Cancer Research UK

Your research papers will be:

- available free of charge to the entire biomedical community

- peer reviewed and published immediately upon acceptance

- cited in PubMed and archived on PubMed Central

- yours - you keep the copyright 